University of Rhode Island

DigitalCommons@URI

Open Access Master's Theses

1983

\title{
THE NATURE OF PENTECOSTAL RELIGIOUS COMMITMENT: VIEWS FROM THE OUTSIDE AND THE INSIDE
}

Robin Louise Gavitt

University of Rhode Island

Follow this and additional works at: https://digitalcommons.uri.edu/theses

\section{Recommended Citation}

Gavitt, Robin Louise, "THE NATURE OF PENTECOSTAL RELIGIOUS COMMITMENT: VIEWS FROM THE OUTSIDE AND THE INSIDE" (1983). Open Access Master's Theses. Paper 1775.

https://digitalcommons.uri.edu/theses/1775

This Thesis is brought to you for free and open access by DigitalCommons@URI. It has been accepted for inclusion in Open Access Master's Theses by an authorized administrator of DigitalCommons@URI. For more information, please contact digitalcommons-group@uri.edu. 
THE NATURE OF PENTECOSTAL RELIGIOUS COMMITMENT:

VIEWS FROM THE OUTSIDE AND THE INSIDE

BY

ROBIN LOUISE GAVITT

A THESIS SUBMITTED IN PARTIAL FULFILLMENT OF THE REQUIREMENTS FOR THE DEGREE OF

MASTER OF ARTS

IN

SOCIOLOGY

UNIVERSITY OF RHODE ISLAND

1983 


\section{ABSTRACT}

This study is an ethnosemantic investigation of a local Pentecostal church. The investigation focused on how the members of the congregation view the nature of their religious commitment. This insider's perception, otherwise referred to as the private face of religiosity, was preserved by employing a research tool known as the ethnosemantic interview. The ethnosemantic approach was especially suited here since its main objective was to discover and describe a cultural system in terms which preserved the insider's point of view. The method avoided the assumption of what was to be considered relevant by making a verbatim record of what an insider said about his/her cultural scene. In addition to the ethnosemantic investigation, participant observation and a short mall questionnaire were employed in the study. These research methods served as cross-checks of and supplements to the interview data.

Aside from investigating a local Pentecostal group's view of the nature of their religious commitment, this study also examined the phenomenon throughout the histories of the Pentecostal movement in general and in the Church of God of Cleveland, Tennessee, in particular. (The latter represents the Pentecostal denomination with which the studied congregation is afflliated.) In this examination, a sociological scheme of the nature of religious commitment 
was utilized and proved successful in organizing the historical material. The applicability of the sociological scheme to this public face of religiosity was not evident when an attempt was made to apply the same scheme to the private face of religiosity. It was found that the local Pentecostal congregation had its own conceptual scheme of the nature of their religious commitment which differed substantially from the standard sociological view. 
ACKNOWLEDGEMENTS

In reflecting back over the long process of completing my thesis, I have realized it is actually the result of many people, all performing different, but crucial roles in 1ts completion. First, I would like to acknowledge the contributions of my committee members, Dr. Calvin B. Peters, Dr. Leo Carroll, and Dr. James Findlay.

Second, I would like to thank The Highway Church of God for allowing me to conduct my research through that congregation. Particularly, I would like to thank my principal informant for his generous cooperation. To all of these people, I wish to express my gratitude for the $1 \mathrm{r}$ continual support and encouragement.

I must also acknowledge my friends whose support without obligation sustalned me through the most trying of times. My special appreciation goes to Sandy Woods, Roseann Kane, and Debbie Giguere.

Finally, I would like to thank my parents, Harold and Vivian Gavitt, for all their support, understanding, and patience. A special thanks also goes to my mother, the most accommodating and inexpensive typist I know. 


\section{TABLE OF CONTENTS}

Chapter

I. Statement of the Problem............ I

Method

A View from the Outside

II. The History of Pentecostal Religion:

A View from the Outside........... 18

Belief

Practice

Knowledge

Experience

Conclusion

III. The Highway Church of God: A View

from the Inside... . . . . . . . . .61

Worship Services

Nonroutine Worship

The Role of Scripture and Knowledge

Hitting the Altar

Hitting the Floor (Being Slain in the Spirit)

Giving Testimony

Confirmation from God

Conclusion

IV. Outsiders and Insiders: Some Conclusions... . III APPENDIX. Cover Letter and Questionnaire. . . . . 118 SELECTED BIBLIOGRAPHY . . . . . . . . . . . . 120 
CHAPTER I

STATEMENT OF THE PROELEM

"When we have a commitment, then it changes our whole nature, everything changes around and eventually comes in line with what God wants. Then, He's happy with us. Amen."

(Informant)

The conception and establishment of any religious institution pivot on the aspect of commitment. Historically, the paramount concern of any religious organization has been to lead people to faith, and the continued existence of any religion would seem to rely on achieving this task (Stark and Glock, 1968). However, despite the importance of religious commitment, the concept remained extremely ambiguous until the research of Rodney Stark and Charles Glock (1968:1-3). Aside from the differences in particular beliefs and practices, Stark and Glock (1968) suggest that there seems to exist considerable agreement among all rellglons on the general ways in which religlousness ought to be expressed. These general ways yleld a set of essential dimensions of religiousness: belief, practice, knowledge, expertence, and consequences."

* Stark and Glock (1968:6) Included the dimension of consequences in their sociological scheme of the nature of religlous commitment. For various reasons, however, including research whlch needed to be satisfactorlly completed before they investigated the consequences of religious commitment, Information concerning the dimension has not yet been published. For this very reason, discussion of the dimension of consequences has been omitted in this study. 
Briefly, since these dimensions will be taken up in greater detail later, the belief dimension includes the expectations that religious people will concede the truth of the terets of their religion. The faithful will engage themselves in an assured theological perspective. Religious practice takes into account acts of worship and devotion, the activities people engage in to execute their religious commitment. The knowledge dimension of religlous commitment presumes that religious people will have some information, even if minimal, concerning the basic tenets of their faith, its rites, scriptures, and traditions. The experience dimension refers to the anticipation that a "properly" religious person will achieve some sense of communfation with a supernatural agency. In every religion a subjective religious experience is valued as an indication of individual religiousness (Stark and Glock, 1968:14-16).

The expression of the foregoing dimensions of religious commitment signifies the physical or apparent manifestations of these behaviors. The demonstration of the dimensions is readily perceived by those who are members, by those who may be considered insiders or nattves of a religlous group, as well as by those people who are unfamiliar with the group (outsiders). The significance of the expressed dimensions to the insider, however, tends to escape the awareness of outsiders as they find themselves on the outskirts of the native's culture. "Discovering the 
insider's view is a different species of knowledge from one that rests primarily on the outsider's view (Spradley, 1979: 4)."

People in their everyday living encounter numerous cultural scenes, some of which are familiar to them and others which are not. Our everyday lives are lived in diverse social situations, handling various problems, carrying out different objectives. Careers, hobbies, clubs, and volunteer organizations all represent diverse cultural scenes with each scene providing a system of knowledge to be used by 1ts members to organize their behavior in ways considered approprlate for the cultural scene in question (Beals, 1979: 109; Spradley, 1979:21). Therefore, any one person possessIng the knowledge of many cultural scenes, will adapt his/ her behavior accordingly, taking on a multiplicity of roles, as he/she shifts from scene to scene during the course of his/her everyday lives. For example, a person who is a parent at home, a vice-president of a business corporation, and a deacon in a church, will adopt the approprlate behavior for such roles as defined by each cultural scene. The behavior exhibited by an individual in a particular cultural system indicates an effort by the Individual to act in a manner deemed appropriate for the system, maintaining certain standards pertaining to the cultural scene (Goffman, 1959:107). The rough and bo1sterous behavior displayed by a person drinking with 
friends in a bar-room would hardly be considered proper behavior for the same person while he was functioning as a deacon at a church service.

One of the most interesting aspects of the mult1cultural scenes a person encounters each day is the change in roles displayed by the person as he/she shifts from scene to scene. As a person moves from one cultural scene to another, a change in character can usually be detected (Goffman, 1959:121-126). To use my previous example, a change can be perceived in the rowdy character displayed by the person drinking with friends in a bar as that person shifts to the more sedate role of a deacon at a church service,

Goffman (1959:136-137) also suggests that Ind1v1duals give the Impression that the role they are playing at any one time is their most important role. This impression can be contradicted, however, if an Individual shares several cultural scenes with the same members who are able to observe the individual's changes in roles. The answer to this problem, according to Goffman (1959:137) 1s for the Individual not to share several cultural scenes with the same people but to "... segregate his audiences so that the Individuals who witness him in one of his roles will not be the individuals who witness him in another of h1s roles."

If one of the cultural scenes of which an Individual is a member dominates their everyday living, however, the Impression of the timely role as the most important may not 
pose a problem. It may be the choice or the hope of an individual that the systems of meaning presented to him/her by one of the cultural scenes to which he/she belongs come to affect his/her behavior in remaining spheres of his/her life. For instance, a person may hope that the systems of meaning bestowed to him/her by the religious group of which he/she is a member influence other realms of his/her everyday life. If part of a religious group's declaration of faith is the understanding that the Bible represents the final authority for faith and practice and an individual wishes to turn his/her religious membership into a way of life, letting his/her membership in this cultural scene influence all aspects of their life, then it is likely that he/she will live his/her everyday life according to the Bible.

The notion that members of various cultural scenes propose diverse systems of meaning for interpreting their experiences and generating social behavior does not indicate that they are out of touch with reality, only that "they classify and interpret the world around them in different but equally valid ways" (Beals, 1979:121; Spradley, 1979:5). The purpose of a classification system for a group is that it allows communication among the members of the group. If an indlvidual lacks access to the systems of classification and meaning held by the members of a particular group, then that person will find him/herself 
unable to function appropriately within the group (Beals, 1979:123-125). As a member of cultural scenes, as an insider, a person acquires the systems of knowledge necessary to permit them to act in the manner particular to the various cultural scenes.

Today, individuals living in a modern, complex society, such as ours, confront numerous cultural scenes in their day-to-day living. Encounters with, and membership in several of the existing cultural scenes lead to individuals living by several different systems of meaning as projected by the var1ous groups in which they find themselves as members, as insiders. Religious groups represent one of the many prevailing cultural scenes providing systems of meaning to their adherents.

The systems of meaning furnished by a religious group, or any other cultural scene, are used by the members to organize their behavior, to understand themselves and others, and to make sense out of the world in which they live. This knowledge consists of typificatory schemes used by natives (1nsiders) to order their everyday actions. The internalization of these schemes allows major routines of everyday life to be carried out as habitualized actions, defining a member's reality and its boundaries. The meanings of the habltualized actions entalled also end up being taken for granted. They are embedded as routines (Berger and Luckmann, 1966). The constructed reality (the 
pattern of behavior) which results from internalizing the routinized actions and meanings specific to a rellgious congregztion represents the culture of a religious group. Outsiders to a particular religious group, through no fault of their own, can not help but fird themselves on the periphery of that culture until such a time as they have acquired the knowledge that a certain congregation uses to make sense out of their experlences and to generate social behavion.

The physical or outward expression of a group's religious commitment is readily observable. The interpretation and significance of such behavior is, however, not as easily perceived. The interpretation and meaning of the manffestation of a congregation's commitment are parts of that culture's knowledge avallable only to insiders of that particular cultural scene. The knowledge acquired by the members of the rellgious group allows them to organize their behavior, to understand themselves and others, and to make sense out of the world in which they l1ve. An outsider to a religious congregation, whether a visitor from another congregation or a university professor with intentions of performing research, w1ll be 1gnorant of the nat1ves' view of the nature of their religious commltment until he/she has acquired the knowledge used by the inslders to interpret and understand their behavior. What can be perceived by an outsider is the apparent, physical or outward expression of 
the dimensions comprising the nature of religious commitment. In the present study, due to personal interest, I have chosen to examine the nature of religious commitment among the members of a local Pentecostal group, hoping to capture the members' view of the nature of their religious commitment as well as the visible expression of their religious commitment.

The present study will not ignore the native point of view but rather will seek to preserve it. The intent of this study is to preserve the native's or insider's view of the nature of religious commitment. The outward demonstration of the nature of the congregation's religious commitment represents an outsider's perception of their nature. The insider's view of his/her actions and their meanings, however, usually differs from outsiders because as an insider one defines his/her behaviors and beliefs differently (Spradley, 1979). The importance of this study lies in preserving the natives' constructed religious reality, which 1 s used by them to make sense out of the world in which they live. In addition, the preservation of the Insider's v1ewpoint permits the observation of alternative realities as defined by those who l1ve them and thereby adds to the richness of soclological data.

\section{Method}

I preserved the insider's perception in this research project by employing an 1nvestigative tool known as the 
ethnosemantic interview. I conducted seven such interviews with my informant over a period of three months. Ethnosemantic investigation was particularly sulted in this study since its main objective is to discover and describe a cultural system from the native point of view. The ethnosemantic approach avoids the assumption of what is to be considered relevant by making a verbatim record of what an insider says about his/her cultural reality. The questions asked of an informant are themselves structured from the verbatim record of what the informant discloses about his/her culture. This technique allows the insider's views to structure both the investigative procedures as well as the data themselves. The analysis of the data involves the extraction of implicit Insider perspectives rather than the imposition outsider categortes. The importance of retaining native terms and perspectives is. frequently underestimated. Researchers, often unintentionally, summarize, translate, and condense Information conveyed to them by informants or members of a cultural scene. This failure to record verbatim the native tepms spoken by informants leads to a distorted and incomplete plcture of what the natives know about the1r culture (Spradley, 1979:73). The language spoken by informants to describe thelr cultural reality holds the key to preserving the native point of view.

The purpose of language here, however, is not limited to presenting a description of a cultural scene. Language 
functions as more than a means of communication about a reality; it serves as a tool for reflecting and constructing reality. The common reflections or objectivations of everyday life are sustained primarily by "IInguistic signification," an Index of subjective meanings. Everyday life within a particular culture is life with and by way of a shared language among the culture's members (Berger and Luckmann, 1966:34-46). The Importance of understanding the language of a distinctive culture cannot be underestimated; it is necessary to an understanding of the everyday reality of that cultural system.

Language forces people into its patterns. The rules of syntax and semantics of one language cannot indiscriminately be transferred to another. Differences between the two languages exist, and, therefore, the direct transference of the rules of syntax and semantics from one language to another would have a profound influence on the content of the message to be communicated (Berger and Luckmann, 1966: 34-46; Spradley, 1979). For example, one cannot use the rules of Spanish syntax and semantics when speaking English, or those of a bar-room when speaking to a religious group. There exist prevailing standards of the proper language for various cultural realities. For instance, Spanish differentiates two verbs of "being," ser and estar, English has only one (Gumperz, 1969:446). Or take the phrase, "It's a miracle!," spoken in the distinct atmospheres of a barroom and a church service. In the former scene, the phrase 
may simply refer to an incident occurring against great odds whereas, in the latter atmosphere, the phrase would refer to an event which surpasses the powers present in the physical world and is ascribed to a divine cause. One can see from these examples the inability to transfer the rules of syntax and semantics of one cultural scene's language to another without distorting the content of message to be conveyed. Language typifies experiences, letting a person belonging to a particular cultural system classify them under broad categories in terms which have meaning for that person and the members with whom he/she shares the cultural system (Berger and Luckmann, 1966:39).

In sum, the above discussion indicates the importance of documenting the language employed by a distinctive culture. Language is an instrument for communicating and constructing reality. Variant languages create and reflect different realities and allow the expression of differing patterns of categorization of experiences. Further, the existence of numerous cultural languages provides alternative methods to culture-bound perspectives of thinking and perceiving. Clearly, the necessity of learning the language of a particular culture is extremely important if one wishes to avoid distorting the systems of meaning used by the members of the cultural group. An ethnosemantic investigation minimizes the distortion of the cultural knowledge used by members of a cultural scene by discovering and describing the systems of meaning of a cultural group from the native 
point of view using native language. Such a method, nevertheless, does have limitations. Ethnosemantic investigation does not eliminate all ambiguity concerning the systems of meaning employed by a cultural group, nor does the method eliminate the need for the researcher to create order out of what an informant has reported (Spradley and McCurdy, $1972 ; 76)$.

These limitations, however, were compensated for by employing participant observation and a short mall questionnaire. The usage of the participant observation method served as a cross-check of and supplement to the interview data, aiding in eliminating ambiguity and creating order out of the data gathered. I attended twelve Sunday worship services at the local Pentecostal church over a period of fiye months. The observations made were elther noted mentally or as condensed fleld notes and shortly thereafter translated into expanded accounts of that observed. The information gathered through the observations was then integrated with the Interview data in order to produce a more complete account of the cultural knowledge used by the members of the local Pentecostal congregation.

The questionnaire served as a final check on the accuracy of the interview data. The congregation being considerably small in size, I talked with only one informant. To ensure that the description I was recelving was a shared cultural depiction and not a personal one, a short mail questionnaire was sent to the households of the members of 
the church group (See Appendix). The data from these questIonnaires corresponded closely with what my informant had told me. This fact indicated I had, indeed, tapped the shared cultural knowledge of the local congregation, The participant observation research method and the questionnaire, when coupled with the ethnosemantic investigation, provided the means necessary to discover the cultural knowledge utilized by the members of a local Pentecostal group in terms which preserve the insider's point of view.

\section{A Vlew from the Outside}

Pentecostalism has received considerable attention due to the nature of its religious comitment. Its unique nature has led its adherents to be labeled "holy rollers." The members are renowned for renunclation of or indifference to the surrounding society and its value system (Chalfant et al., 1981:123; Dearman, 1974:439). For Pentecostal members, the Blble 1 s viewed to be the norm and final authority for faith and practice (Hollenweger, 1972:52; Nichol, 1966:2).

"God has written through supernaturally inspired persons a book (the Bible) whlch is literally perfect and which contains all great truth and wisdom. Anything which in any way contradicts this book 1s wrong and false (Wood, 1965:17)."

Pentecostal worship services are described as informal, often emotionally gulded services. Worship services are characterized by emotional intensity and spontaneous 
expression of religious feelings. This fervor and enthusiasm are seen 1 n such activities as dancing, jumping, jerking, and falling on the floor (Boisen, 1955; Chalfant et al., 1981:123; Gerlach and Hine, 1968; Hollenweger, 1972; W1lson, 1963:365). Because of their special emotionalism, Pentecostals are reported as having a sense of elitism in which ldentity with the group suggests discovery of the one absolutely "true way" of I1fe (Chalfant et al., 1981:123; Dearman, 1974:439440; Willems, 1967:254).

Pentecostalism does not differ from other religions in assuming its followers will possess some minimal information pertaining to the basic tenets of their religion. Pentecostals, however, hold an antipathy toward education which extends beyond that which will make their lives richer in the ways of the Lord (Nichol, 1966:78). Aversion toward education in the early days of Pentecostalism was based on several assertions. First, education was viewed as being harmful to spirituality. Next, the tremendous cost of creating and malntaining educational facilities would necessitate the diverting of funds from highly valued spiritual endeavors such as home and foreign mission programs. Third, education was rejected because it was feared that the ministers would come to be Judged for their educational background rather than for their spiritual leadersh1p. Further, it was believed "that the words of Jesus as in John 16:13 ('When the Spirit of truth comes, he 
will guide you into all truth...') signify that the Holy Spirit persoially instructs the believer; therefore, it is unnecessary to proviue either religious or secular training (Nichol, 1966:231)." FInally, since most of the adherents of the Pentecostal churches came from the lower social and economic strata and most had not advanced past the secondary school level, Pentecostal members had very little, if any, value for education in general and for higher education specifically (Nichol, 1966:230-231).

As the Pentecostal movement grew, however, the climate of opinion toward education changed somewhat. Pentecostal administrators realized that thelr members and youth were proceeding through life wlthout any training in PentecostalChristian principles. As a result, Blble institutes, Bible colleges, and liberal arts colleges were established by various Pentecostal denominations to allow for "collegiate education In a Pentecostal atmosphere (Nichol, 1966:231232)." Such an atmosphere, nevertheless, did not and does not now permit fair attention to certain 1deas that other, secular educational institutions give to the same 1deas. Pentecostal adherents, for example, are reported to reject deterministic explanations of behavior, to reject Darwin's theory of evolution. A current of thought such as Darwinism is considered a "false doctrine" against which the Pentecostal movement protests (Synan, 1971:57). Pentecostal members cannot accept the theory of evolution which, for them, consists of heretical teachings. 
Pentecostals view Darwinlsm as a "denial of ancestral authority" but more importantly, as a contradiction to their belief in creation (Hollenweger, 1972:273, 296).

Disputes over the place of such currents of thoughts as Darwinism in religion are not new in the religious community. "Long before America was discovered, the Christian community was perennially divided between those who belleved that intellect must have a vital place in religion and those who belleved that intellect should be subordinated to emotion, or in effect abandoned at the dictates of emotion (Hofstadter, 1970:55)." Pentecostal congregations have been described as adhering to the latter opinion of this continuing annual partition in the Christian communty, pursuing education mainly in a "Pentecostal atmosphere" in order to enrlch their lives in the ways of the Savior they worship.

An emphasis on emotional experiences is a distinction often noted of Pentecostal groups. Pentecostals "attach a great significance to the relationship between the individual and a personal savior, a relationship expressed in direct emotional terms rather than in a symbolic or ritualistic manner (W1lson, 1963:365)." Examples of experience among Pentecostals indicating the described subjective religlous relationshlp with their Savior are: baptism with the Holy Spirit, speaking in tongues, and faith healing. A profound feeling of and essentlally personal 
relationship with God stands firm among Pentecostal Individuals.

This description of the nature of Pentecostal commitment is just that - a description. The depiction presented describes from an outsider's perspective the physical or outward expression of the dimensions comprising the religious group's nature of commitment. The native or Insider's view of the nature of their religious commitment is not discussed. The interpretation and meaning of the manifestations of the Pentecostal group's commitment, used by the members to order their everyday actions, have virtually been ignored. This gap between "outsider" and "Insider" is what this study intends in part to fill. 


\begin{abstract}
CHAPTER II
THE HISTORY OF PENTECOSTAL RELIGION:
\end{abstract}

A VIEW FROM THE OUTSIDE

A religious group's definition of its reality is not created and maintained in a vacuum. Cultural reality does not exist in isolation, exempt from outside forces. In order to properly understand and assess a religious group's constructed reality, one should examine its history (Hamilton, 1975:41). The history of the religious movement from which a particular religious group results is part of the context in which the members of that group are likely to define themselves. A group's history provides a foundation on which the group's members can construct and maintain their reality.

In the present study, the history of concern is that of the Pentecostal movement within the United States. A complete account of the movement's history, however, will not be attempted. The volume of such information is enough to fill numerous books, let alone a single chapter. Instead, selective histories of the Pentecostal movement in general, and of the Church of God of Cleveland, Tennessee, in particular will be presented. The latter represents the Pentecostal denomination with which the studied congregation is affiliated. This chapter is focused on Pentecostal religious commitment, comprised of the dimensions of belief, 
practice, knowledge, and experience. Such an emphasis on the nature of religious commitment will serve to highlight the contexts likely to have influenced the notion of religious commitment in the local congregation I examined. Further, the history of Pentecostal religious commitment will serve to illustrate the usefulness of the sociological scheme of commitment proposed by Stark and Glock (1968). This sociological scheme is useful when examining material which represents the physical or outward expression of events occurring throughout the Pentecostal movement; that is, material which constitutes the history of the movement. Stark and Glock's (1968) conceptual strategy is functional when investigating information which denotes an outsider's view of Pentecostal religious commitment. So, before encountering the local Pentecostal group's definition and interpretation of the nature of their religious commitment, I will first look at the dimensions of this phenomenon throughout the histories of the Pentecostal movement in general and in the Church of God of Cleveland, Tennessee, in particular.

Before beginning the discussion of the history of the dimensions of the nature of Pentecostal commitment, however, It should be noted that as a religious group's definition of its reality is not developed and maintained in isolation from outside agents, a similar conception applies to the differing dimensions of religious commitment. Although 
the various dimensions will be discussed here separately, no one dimension exists in seclusion, apart from the others. In fact, the dimensions are often related. For example, by definition, the knowledge dimension of religious commitment holds the presumption that religious people will possess some minimal level of information concerning the beliefs and practices of their particular faith (Stark and Glock, 1968: 16). Here, even though we can talk about the dimension of knowledge as a dimension distinct from the others comprising the nature of religious commitment, it is clearly related to and affected by other dimensions, namely, those of belief and practice. So, while the history of each dimension of the nature of Pentecostal commitment will be examined individually, it should be remembered that the dimensions, in reality, did not and do not today, exist in isolation from each other.

\section{Belief}

The first dimension of the nature of religious commitment to be discussed in light of the Pentecostal movement is that of belief, the dimension believed to be at the core of all religions (Stark and Glock, 1966:3). The doctrinal lineage of American Pentecostalism is to be found in the Wesleyan tradition. John Wesley, the undisputed founder of Methodism, is also claimed to be "the father" of the moderr Holiness and Pentecostal movements which have derived from Methodism within the last century (Hamilton, 1975:77). 
By 1740, Wesley's notions on theology were fairly well stated in the permanent form that would fashion the Methodist movement. Wesley's theology involved two separate phases of experience for the believer: conversion or justification; and Christian perfection or sanctification. In the first instance,

"...the penitent was forgiven for his actual sins of commission, becoming a Christian but retaining a 'residue of sin within.' This remaining 'inbred sin' was the result of Adam's fall and had to be dealt with by a 'second blessing, properly socalled.' This experience purified the believer of inward sin and gave him 'perfect love' toward God and man (Synan, 1971:18)."

The perfection which Wesley taught was not a "sinless perfection" but a perfection of motives and desires. The notion that a person might sin again was an 1dea that would remain real throughout Wesley's teachings. The Wesleyan doctrine of Christian perfectionism or entire sanctification became the characteristic doctrine of Methodism and so it became the first great Holiness church (Synan, 1971:18-19). When Methodism arrived in America during the $18 \mathrm{th}$ century, the doctrine of entire sanctification was transplanted along with 1t. Wesley termed Methodist perfectionism in America, the "heart religion." The doctrine leaned toward warmth, experience, and morality and away from the mechanical and formal worship of the times. Perfectionism was finding its way as one of the principal themes of American religion by 1870 (Synan, 1971:19-28). Despite such popularity of the doctrine of holiness, however, conflict 
over it began to be felt in the Methodist Church during the $1880^{\circ} \mathrm{s}$ as more and more Methodist leaders questloned the basic premises of the Holiness movement. The controversy concluded in a rejection of the Holiness movement and an attack on its adherents. The direct result of the attempt to exterminate Holiness groups, however, was the creation of numerous new "Holiness" denominations and churches. The development of the new churches led to the formation of the group of denominations known as the Holiness movement, and an even larger group which became known as the Pentecostal movement (Synan, 1971:45-54).

Two particular Holiness churches fated to play a significant role in the Pentecostal movement were the FireBaptized Holiness Church and the Pentecostal Holiness Church, both of which were considered radical Holiness denominations. The Fire-Baptized Holiness Church was founded in Iowa in 1895 by Benjamin Hardin Irwin. This denomination, in the doctrinal sense, was a direct forerunner of the modern Pentecostal movement - "By teaching that the bapt1sm of the Holy Ghost was an experience separate from and subsequent to sanctification, it laid the basic doctrinal premise of the later movement (Synan, 1971:68)."

Next, the Pentecostal Holiness Church had its beginnings in North Carolina in 1900 under the leadership of the Reverend A. B. Crumpler. Crumpler's Pentecostal Holiness Church was quite similar to other holiness groups 
in that its statement of faith included all the usual Wesleyan language regarding entire sanctiflcation or Christian perfectionism as a second definite phase of experience for the bellever. Other holiness doctrines, however, did mark this denomination as part of the radical branch of the holiness movement. Divine healing and premillennialism were doctrines held by the Pentecostal Holiness Church as well as restrictions against "worldliness," "oyster stews," "needless ornamentation," and "tobacco" (Synan, 1971:71-72).

Ideologically, then, the Hollness movement provided several emphases which have become the very crux of Pentecostalism. These emphases have been summarized by John Nichol (1966:7) as follows:

(1) that there is a blessing to be sought and to be received subsequent to and distinct from conversion;

(2) that one must seek to be led by the spirit in all the affairs of life;

(3) that revivals and camp meeting ought to be utilized for the purpose of winning converts and refuvenating the spiritual lives of the faithful;

(4) that believers should maintain a vibrant hope in the imminent return of Christ; and

(5) that one ought to forsake the world and shun all manifestations of "worldliness" amusements, jewelry, use of cosmetics, luxury.

A doctrinal revolution occurred in 1906 at the renowned Azusa Street revival in Los Angeles where the phenomenon of speaking in tongues, otherwise known as 
glossolalia, was experienced. The person responstble for introducing glossolalia as a formally stated doctrine was the Reverend Charles Fox Parham of Kansas. Parham distinguished speaking in tongues as the single evidence of one's having recelved the baptism with the Holy Splrit. It was also Parham who taught that this practice should be included as a regular occurrence at Christian worship services rather than a curlous manifestation of religious enthuslasm. The Reverend Parham's teachings can be sald to have provided the doctrinal foundation of the modern Pentecostal movement. Parham's thoughts preached by his followers, particularly W. J. Seymour, produced the famous Azusa Street revival and with 1 t the phenomenal growth of the Pentecostal movement (Synan, 1971:95-99).

W. J. Seymour, the distingulshed preacher of the Azusa Street revival, recelved his theologlcal training at a Bible school in Houston, Texas, operated by Parham. There, Parham taught Seymour that the Holiness movement had erred In proposing that sanctification was also the baptism with the Holy Splr1t. For Parham, the latter event was a "thlrd experlence," separate in time and nature from the second event of sanctification (Synan, 1971:103). "Sanctification cleansed and purfified the believer, whlle the baptism with the Holy Splrit brought great power for service (Synan, 1971:104)." Further, Parham held that the only B1blical evidence of one having recelved the bapt1sm with the Holy Splrit was the act of glossolalia as the disciples had 
experienced on the Day of Pentecost. This notion was the very one which was preached by Seymour at the Azusa Street revival, namely, that every person who received the "baptism" would respond as the disciples did on the Day of Pentecost, that is, speak in tongues (Kildahl, 1972:18; Nichol, 1966:32).

In addition to the outbreak of tongues at Azusa Street, an important part of the early stages of the revival was the healing ministry. The emphasis on divine healing, undoubtedly, was responsible for drawing large crowds in the early days. The doctrine of divine healing was and has remained one of the most distinctive Pentecostal tenets. Healing is preached because Pentecostal adherents believe that liberation from physical illness is the right of all believers (Menzies, 1971:58; Nichol, 1966:15-61, 63).

The significance of the Azusa Street revival, however, was that it acted as the agent which made tongues-speaking into a fully defined doctrine. The phenomenon had been manifested throughout the history of the Christian Church but had never been regarded as a necessary evidence of the baptism with the Holy Spirit (Nichol, 1966:19; Synan, 1971: 119-121). It was Parham's contention that glossolalia was necessary as the only "bilbical evidence" of the Holy Spirit baptism which caused disunion within the Holiness movement. The adherents of the Pentecostal doctrine settled on one 
Indisputable evidence which was supported by biblical citations and was the same for all.

Uniform Pentecostal doctrine, nonetheless, was not to remain unadulterated through time. The years 1914 to 1919 have been recognized as a period of schism and realignment over doctrinal and theological issues. First, around 1914, the movement saw 1ts most fundamental doctrinal severance. A bitter argument arose between two sectors of the Pentecostal movement over the issue of sanctification as a second work of grace. The conflict pitted those Pentecostals who entered the movement with Holiness or Wesleyan backgrounds against those who had emerged from the Baptist denominations (Nichol, 1966:87; Synan, 1971:147, 192). In the first instance, the believers strossed the "second work of grace" theory, believing there is an experience subsequent to salvation whereby the believer is "entirely sanctifled." The latter case, promulgated by William H. Durham, sought to invalidate the notion of sanctification as a second work of grace. Durham called his new doctrine, "The Finished Work,"proposing a view which reassigned sanctification to the act of conversion based on "the finished work of Christ on Calvary." Durham taught "that one was perfectly sanctifled at conversion and had no need of a 'second change' later (Synan, 1971:148)." The controversy over the "finished work" issue dissolved the period of doctrinal unity which had existed 
within the Pentecostal movement since 1906. After 1914, the Pentecostal movement continued with members about equally divided between advocates of the "second work" and advocates of the "finished work" (Synan, 1971:153). Due to this doctrinal cleavage, all hope of a merger of all Pentecostal adherents into one body was discarded.

A second theological division occurred in 1916 over the "Jesus Only" issue. Proponents of this view insisted on baptism or rebaptism in the name of Jesus only as they believed that God the Father and the Holy Spirit were only "titles" referring to Jesus Christ, who alone made-up "the Godhead" (N1chol, 1966:90; Synan, 1971:220-221). As a result of this denial of the Trinity, new Pentecostal denominations arose which were to be committed to the "Jesus Only" view.

Overall, much like the Holiness movement from which they emanated, Pentecostals do not feel they have devised any new doctrine or rules. They trust that by preaching the "full gospel" they have simply been re-accentuating old doctrines. Such doctrines include: (1) the biblical significance on salvation and fustification by faith;

(2) the premillennial return of Christ; (3) an emphasis on divine healing; and (4) baptism with the Holy spirit, evidenced by tongue-speaking, which affords a believer a spiritual capacity for extending that of one's natural abllities (Nichol, 1966:7-8). These doctrines, along with others not mentioned here, have been ridiculed and/or 
rejected by numerous members of American society. Yet they have persisted. People are now beginning to acknowledge the phenomenal growth and Influence of Pentecostalism in modern religious history (Nichol, 1966:244-245).

One Pentecostal denomination contributing to the growth and influence of the Pentecostal movement at large is the Church of God of Cleveland, Tennessee. This denomination is one of the oldest and most prominent branches of Pentecostalism in the United States. The doctrinal position of the Church of God is similar to that of the other Pentecostal groups which emerged from the Holiness movement, emphasizing sanctiflcation and personal holiness (Nichol, 1966:101).

The doctrine of entire sanctification reached the people located in the hills of Western North Carolina in 1896 when William Martin, Joe M. Tipton and Milton McNabb arrived from East Tennessee and held a revival in the Schearer Schoolhouse in Cherokee County, North Carolina. These three were self-proclaimed "evangelists" belonging to local Methodist and Baptist churches (Synan, 1971:80-81). The men became preachers of sanctification, claiming an experience similar to that of John Wesley. The preachers taught that sanctification was a particular and definite experience, distinct from the bapt1sm of the Spirit and from conversion (Hollenweger, 1972:50). "They urged people to seek a definite spiritual experience of sanctification which 
would make holiness not only possible but natural (Conn, 1955:17)."

The hill folk of western North Carolina were transformed in this revival. People who had been disruptive became upright; drunkards stopped drinking; people who had been violent became docile. Holiness to these people was a practical way of living made possible by a godly work of sanctification (Conn, 1955:23). The revival that began in the Schearer Schoolhouse in 1896, stressing sanctification and personal holiness, formed the nucleus of what later became known as the "Church of God" of Cleveland, Tennessee (Synan, 1971:81).

As several congregations of the Church of God of Cleveland, Tennessee began to emerge and grow slowly larger, the groups' desire to malntain a close union between the congregations became of concern. In order to fulfill this preference of the congregations, the idea of an Annual Assembly was concelved in 1905 with the First Annual Assembly meeting taking place on January 26-27, 1906. It was to be at these meetings that all final decisions of the growing Church would be made so that the programs of the varlous congregations would revolve around the same nucleus (Conn, 1955:69).

The Second Annual Assembly witnessed a growth in the body of Pentecostal doctrine. The stress at this meeting was placed on spiritual gifts, divine healing, and the 
baptism of the Holy Ghost. The Church of God has consistently taught and adhered to the fundamental and evangelical doctrines of Christianity, with an emphasis on a life of deeper spiritual1ty for its members (Conn, 1955:75-88). The doctrinal solidarity of the Church of God is a un:que characteristic of the denomination. "It has frequently changed 1ts adminlstrative structure and its rules of membership, but not once has it changed a single doctrine it has held from the beginning (Conn, 1955:272)." At the 1948 Assembly, the need for a Declaration of Faith was discussed. A commlttee was appolnted to complie such a document. The Declaration issued was not an exhaustive document of Faith, however, the Assembly accepted 1t. The Short Declaration, which has become the official statement of the Church of God belief, reads as follows:

We belleve:

1. In the verbal insplration of the Bible.

2. In one God eternally existing in three persons; namely, the Father, Son, and Holy Ghost.

3. That Jesus Christ is the only begotten Son of the Father, concelved of the Holy Ghost, and born of the Virgin Mary. That Jesus was cruclfled, burled, and raised from the dead. That He ascended to heaven and is today at the right hand of the Father as the Intercessor.

4. That all have sinned and come short of the glory of God and that repentance is commanded of God for all and necessary for forgiveness of sins. 
5. That justification, regeneration, and the new birth are wrought by faith in the blood of Jesus Christ.

6. In sanctification subsequent to the new birth, through faith in the blood of Christ; through the Word, and by the Holy Ghost.

7. Holiness to be God's standard of living for His people.

8. In the baptism with the Holy Ghost subsequent to a clean heart.

9. In speaking with other tongues as the spirit glves utterance and that it is the initial evidence of the baptism of the Holy Ghost.

10. In water bapt1sm by immersion and all who repent should be baptized in the name of the Father, and of the Son, and of the Holy Ghost.

11. Dlvine healing is provided for all in the atonement.

12. In the Lord's Supper and washing of the saints' feet.

13. In the premillennial second coming of Jesus. First, to resurrect the righteous dead and to catch away the living saints to $\mathrm{H} 1 \mathrm{~m}$ in the air. second, to reign on the earth a thousand years.

14. In the bodlly resurrection: eternal life for the righteous and eternal punishment for the wlcked (Conn, 1955:281).

This Declaration of Falth is viewed as a proclamation of the tenets of falth first established forty-two years earlier by the twenty-one Pentecostal bellevers present at the First Annual Assembly (Conn, 1955:281-282). In forty-two years of change and expansion, the Church of God of Cleveland, Tennessee has kept pace w1th its t1me regarding 1ts program 
and methods. Doctrinally, however, it claims to be the same Church it was since its inception at the turn of the century.

\section{Practice}

The second dimension of the nature of religious commitment to be discussed with regard to the Pentecostal movement is that of practice. The practice dimension throughout the Pentecostal movement includes acts of worship and devotion, acts of formal and informal natures which were performed in order to carry out religious commitment.

Several Pentecostal. practices of a formal and public character were displayed at worship services characterized by emotional fervor, spontaneity, and warmth (Synan, 1971: $22,200-201)$. Such ceremonial practices included general prayer, music, glossolalia, and healing. General prayer was a practice at church services in which prayer was slmultaneously voiced by the attending congregation. The effect of this practice was often times that of a dissonant mixture of voices. At times, however, the practice produced a chorus of harmonized sounds (Boisen, 1955:82).

The use of music is noted as being one of the causes for the Initial success of Pentecostalism. In their music, Pentecostals provided extensive opportunity for emotional release and for a high degree of participation thereby meeting psychological needs of people (Menzies, 1971:78; Nichol, 1966:64). The general effect of Pentecostal singing was to glve a person the sense of being entangled and fused 
with the group. The various practices associated with Pentecostal music - dancing, clapping, use of various musical instruments, and zealous singing, "sanctified" activities which were otherwise abstained from - have been reported as compensation for the strict moral code adopted by the Pentecostals (Menzies, 1971:78).

Third, the practice of glossolalia or speaking in tongues is reported as unique in its capacity to fulfill several roles. As was cited in the previous section, the practice of glossolalia was introduced first, as a formal doctrine by the Reverend Charles Fox Parham in approximately 1904. Parham declared "speaking in tongues" as the sole evidence of one's having received the baptism with the Holy Ghost. Parham then went on to teach that glossolalia should be a part of regular worship services rather than a peculiar result of religious fervor. These precepts, taught by Parham, laid the doctrinal foundations of the modern Pentecostal movement (Synan, 1971:99). GIossolal1a also fulfilled a third role in that a person might possess the "glft" of tongues, one of the nine gifts of the Spir1t. The usage of glossolalia, in this instance, was for the enlightenment of the church. When manifested it was often followed by an interpretation (N1chol, 1966:13). Because of 1ts abll1ty to fulfill several functions, the importance of the practice of glossolalia should not be underestimated. 
Lastly, the practice of divine healing has occurred intermittently in Pentecostal churches. While the doctrine of divine healing has consistently been stressed by Pentecostal churches, the actual practice was uncommon until 1945. "In the years following V-J Day, the practice of praying for the sick was revived on a scale hitherto unknown (Nichol, 1966:221)." Healing has been practiced by Pentecostal adherents for the same reasons it has been preached by them, namely, "...because Pentecostals believe that deliverance from physical sickness is provided for in the atonement and is the privilege of all believers (Nichol, 1966:16)." Pentecostal practices of a public nature were also exhiblted apart from worship services. These practices Included camp meetings and foreign missions. First, the history of Pentecostal camp meetings extends back to what may be considered the start of the modern Holiness movement In the United States - the Vineland, New Jersey camp meeting on July 17, 1867. The Vineland camp meeting, the first "National Camp Meeting for the Promotion of Holiness," initiated a new era in Methodism, an era embraced by the birth and growth of the modern Holiness movement from which the Pentecostal movement eventually emerged (Synan, 1971:37). The Vineland camp meeting and several camp meetings thereafter, although interdenominational, were dominated by Methodists. The camps took place mainly on Methodist campgrounds and in affiliation with Methodist annual conferences. 
The old-time revival se:vic.s wion rad teen the usual ritual at these cenp meetings, riwever, eventually began to fade out in ir hodism. Metings rilled with religious enthuslasm and its "shouts and hallelujahs" were being replaced with services which included lectures on semireligious and secular topics (Synan, 1971:37-42).

Meanwhile, during this period, the Holiness movement had found unusual acceptance in the Methodist Church. One of the reasons for the movement's acceptance was the belief by many that "...the National Holiness Movement might save the camp meeting, which seemed on the verge of dying out in Methodism (Synan, 1971:41)." Adherents of the Holiness crusade felt that the movement could save the normal ritual of the old-time revival service with all its religious fervor. Indeed, the National Holiness Movement was successful in rejuvenating the camp meetings (Synan, 1971:42). Further, when Pentecostal meetings were established, they inherited the enthusiastic religious fervor of the camp meetings revived by the National Holiness Movement. Pentecostal meetings "promoted holiness" as did the early Methodist meet1ngs (Synan, 1971:217, 223).

A second Pentecostal practice of a public character, exhibited apart from church services, is forelgn missions. "The sacrifice and devotion of Pentecostals in the area of foreign missions...enabled them to gain adherents rapldy (Nichol, 1966:67-68)." The Pentecostal missionary program 
in its early days was a "faith" endeavor. The workers of the program were not guaranteed any definite amount of support. Rather, they were promised that any available funds would be faithfully distributed to them (Nichol, 1966:68). The Pentecostal missionaries and their message were greeted with a warm reception in other lands. The principal reason which accounted for such a warm acceptance of the missionaries was believed to be the policy of establishing Indigenous churches. Pentecostal mission directors proclaimed that they did not send workers to "Americanize" people in other lands but to help establish national self-supporting churches, to let the people guide their religious ways according to their own interpretation of the Blble. It is claimed that such a policy was not initiated consciously. Nevertheless, 1t did prove to be successful and was later imitated by many of the larger denominations (N1chol, 1966: 68).

Pentecostals also exhibited practices of a more private and informal nature. While some of these practices were positive in nature, for example, private prayer and dally reading of the Bible in the privacy of the bellevers' homes, many others involved strictures on the behavior of Pentecostals in their day-to-day living. Since a great number of Pentecostals came from the Holiness movement, they naturally held rather puritanical views regarding dress and needless ornamentation, eating hablts, tobacco and alcohol, 
and so forth (Hollenweger, 1972:401-402; N1chol, 1966:80, 91; Synan, 1971:72).

For example, among some Pentecostal groups during the early days of the movement, members were forbidden to wear flashy colors in dress, short dresses, low necks, bright ties, etc. The practice of wearing unnecessary jewelry rings (sometimes including wedding rings), ear-rings, bracelets, and pins - was also frowned upon by some (Hollenweger, 1972:402; Nichol, 1966:91). Restrictions regarding eating habits Involved taboos against certain foods. For some Pentecostal groups, pork was condemned, while for others, it was snakes, fish, the blood of animals, and so forth. The violation of a food taboo often brought with 1t the duty of the church to discipline the offender (Hollenweger, 1972:402).

Further, most Pentecostals opposed the use of tobacco and alcohol. They renounced smoking as unchristian and, except for Pentecostals residing in Europe, they all abstalned from alcohol (Hollenweger, 1972:401-402; Nichol, 1966:93). As noted, however, these practices, along with the others discussed, were not displayed by all Pentecostal groups. B1tter disputes were often erupted between groups who exhorted aiffering practices, each firmly believing in their own activities and unwlling to depart from them. For each group, the success in carrying out their respective practices in their day-to-day living, meant that they were 
that much closer to living a life of "victory over sin" (Synan, 1971:19).

Various Pentecostal practices, however, elicited hostility toward early Pentecostals from both within and cutside of the movement. Early Pentecostals were suspected by outsiders of practicing everything peculiar and erroneous. Much of this suspicion was evoked by extremists within the movement whose activities such as snake-handling, trances, and the use of magical powders, supported the fabrications already in circulation (Synan, 1971:186). Similar criticisms of Pentecostal practices from within the movement also focused on the actions of extremists. For example, when the Reverend Charles Fox Parham arrived at the Azusa Street Revival in Los Angeles in 1906, "...he was shocked by the 'holy roller' aspects of the services and made efforts to correct the 'extremes and fanaticism,' which he felt had gone 'beyond the bounds of common sense and reason' (Synan, 1971:112)." Parham was asked to leave the meeting because of his criticisms. Even after being barred from Azusa Street, Parham criticlzed its leader, W. J. Seymour, and "...continued his denunciation of the Azusa Street meeting as a case of 'spiritual power prostituted' to the 'awful fits and spasms' of the 'holy rollers and hypnotists' (Synan, 1971:112)."

Other striking practices exhlbited by Pentecostals also evoked public criticism. Such activities included 
speaking in tongues, interpretation of tongues, and the "laying on of hands" for divine healing. Despite the fact that these practices were regarded by Pentecostal adherents to be signs that members were "possessed" by the Holy Spirit, skeptical outsiders consldered them to be signs of lunacy and fanaticism (Synan, 1971:187-188). In summary, therefore, while criticisms of assorted Pentecostal practices, from both within and outside of the movement, were at times one and the same, other instances displayed a profound difference of opinion.

In focusing our concentration on the Church of God, the denomination's desire to maintain a close association between congregations by means of Annual Assemblies, must again be recognized (see p. 28). The Annual Assemblies served as meetings where all final decisions of the Church would be made so that the programs of the various congregations would be founded on the same bases (Conn, 1955:69). Some of the decisions made at the Annual Assemblies Involved declaring which practices would be conducted by the local church groups.

Durlng the First Annual Assembly in 1906, the delegates representing the four churches then established, disputed several practices of a formal and public character including foot-washing and Sunday schools. It was resolved by the delegates that foot-washing was an established rite on the same level as the sacrament of communion and should 
be executed by each local church at least once a year (conn, 1955:65; Synan, 1971:87). The delegates also supported and approved the organization of Sunday schools in the programs of the local congregations (Synan, 1971:87).

Besides disputes over foot-washing and Sunday schools at the First Assembly, the representatives debated the addition of family worship services and midweek prayer services to each church's weekly program. Family worship was stressed as essential to every Christian household and subsequently the proposal of weekly family worship services was approved (Conn, 1955:65; Synan, 1971:87). The Assembly's wish to insert midweek prayer services as part of each congregation's weekly schedule was also accepted. These services, however, were not urged as preaching episodes but as occasions for "devotional and 1nspirational worship" $($ conn, 1955:65).

In addition to making decisions at the Annual Assemblies about which practices would be carried out by local church groups, the Assemblies themselves exhibited practices also exercised in local worship services. Such practices Included divine healing and glossolalia or speaking in tongues.

In every Assembly there were remarkable spiritual manifestations. Many affected persons were healed sometimes in the regular services and sometimes in special services held for the purpose of praying for the sick. Frequent messages were given in tongues and interpreted, generally an exhortation of admonition to more devoted christian l1ving... (Conn, 1955:136). 
Church of God practices of a public nature were also displayed independently of church services. As with the Pentecostal movement in general, these practices involved camp meetings and foreign missions. Although camp meetings had been common in some places during the early years of the Church of God of Cleveland, Tennessee, it wasn't until the Nineteenth Annual Assembly (1924) that a camp meeting for each state was supported and encouraged. Soon, every state had an annual camp meeting lasting anywhere from three days to two weeks in length, with each day full of different services - song, worship, preaching, etc. - from before dawn until after midnight. Today, the annual camp meeting is an expected practice of every state's schedule although, the duration of the meetings is somewhat shorter - generally lasting about one week (Conn, 1955:197-198).

The Church of God's foreign missions program began in 1910 with R. M. Evans, thelr first missionary. The Church was not able to offer Mr. Evans a "faith" program, assuring him that any avallable funds would be faithfully distributed to him. Therefore, Evans' mission was without financial support from the Church. Evans sold his home and his few farm antmals in order to buy a wagon and a team of mules. Along with his wife, he drove three hundred miles to Miami, Florlda, stored the wagon, and sold the mules. W1th the proceeds, Evans booked passage for himand his wife to the Bahamas. Although the Church of God's missions program 
began under unstable conditions, the program has since been characterized by increasing activity (Conn, 1955:258; N1chol, 1966:68).

Another practice of a public nature carried out by the Church of God denomination is the revival. Revivals have been a part of the Church of God of Cleveland, Tennessee, since its early days, with one of its first revivals occurring at Camp Creek. The Camp Creek revival consisted of singing followed by testimonies, in which people stood and shared with the others their spiritual experiences. These testimonies served to comfort and inform those who had gathered together. After the testimonies, came the time of prayer. The time of prayer at the revival was similar to what was referred to as "general prayer" earlier in this section (see p. 31). Prayer was simultaneously volced by all those in attendance, producing a concert-like effect. This was followed by the sermon by one of the evangelists present and a call for sinners wanting to repent and seekers for the experience of sanctification to meet at the altar (Conn, 1955:18-19).

In addition to the activities present at the Camp Creek revival, revival services were also accompanied by such demonstrations as weeping, trances, dancing, glossola11a, Interpretations, and other actions (Conn, 1955:98-99). Revivals, with all their fervor and enthuslasm, continued. Preachers continued to be sent to areas believed ready for 
revival, ready to hear the message of the Church (conn, $1955: 121,132)$.

Finally, two other practices of a public sort are recognized by the Church of God, namely, orphanages and women's groups. The first orphanage was opened on December 17, 1920 under the direction of Mrs. Lillian Kinsey. Mrs. Kinsey had four children under her care. Although it was a small beginning, "...the care of orphans would become a permanent and prominant facet of the Church of God and 1ts mission upon the earth (Conn, 1955:153)." The care of orphans was an outstanding aspect of the local congregation studied for the present project.

To be falr to the many women's groups which existed throughout the history of the Church of God of Cleveland, Tennessee, the groups' works must be recognized as more than material and physical. Many women's groups met for devotions, for prayer, for handing out l1terature, for visiting people at their homes or in the hospltal, or for other charitable purposes (Conn, 1955:246-247). The women at the local Pentecostal Church also met for some of these same purposes.

Adherents of the Church of God also carrled out practices of a private and informal character. Many of these practices involved restrictions on the behavior of adherents in their everyday living. For example, members of some congregations were forbidden such things as meats, 
sweets and medicinal foods. Also, as was common in most Pentecostal denominations, the use of tobacco was forbidden; the habit was viewed as imnoral. The strong condemnation of the use of tobacco in the Church of God of Cleveland, Tennessee has been prevalent in the Church's movement since it was agreed upon by the delegates at the First Annual Assembly in 1906 (Conn, 1955:41-42, 66; Synan, 1971:87). Various Church of God practices, not unlike those of the Pentecostal movement in general, evoked criticism. Public criticism of members of the Church of God and some of their practices originated from outsiders perceptions of an obsession by the Church's adherents to be spiritual. The public sensed such an intense desire by members to be spiritual that the things not even enjoined by the Scriptures were forbidden. Members of the Church who performed such practices, however, did not view them as the outsiders did. Members, who frantically wanted to be spiritual, had been led to believe that the more severely they restrained their desires, the more christ-like their natures would become (Conn, 1955: 41-42).

Members of the Church of God also did not agree with the criticisms addressed to them In response to the emotional features of their services. Because of the emotional aspects of most worship services, the ep1thet "holy rollers" was frequently appl1ed. The phrase, "holy rollers," however, has been declared a misnomer by members since 
"rolling" is very rare during services (Conn, 1955:91, 130). In sum, unlike the Pentecostal movement in general, public criticisms lodged against Church of God members and some of their practices were not concurred in by people within the church. At least, I did not come across any such agreement in the research for this project.

\section{Knowledge}

The knowledge dimension of the nature of religious commitment is a necessary dimension in the sense that the tenets and practices of a religion must be known if they are to be believed and acted upon (Stark and Glock, 1968:141). The beliefs and practices of a religion, however, may also be adopted in "virtual ignorance." They may be seriously clung to but not understood. Therefore, religious institutions look for their members to do more than recognize the basic tenets and practices of their religion. They expect a certain level of comprehension (Stark and Glock, 1968:141). The topic of this section involves an investigation into the means provided by the Pentecostal movement, apart from worship services, to help its adherents gain an understanding of the beliefs and practices peculiar to the movement. To the disadvantage of the Pentecostal movement's desire to aid members in acquiring a comprehension of its doctrine and practices, many of the movement's early leaders were anti-intellectual. The leaders belleved that it was better to be "divinely trained rather than book trained," 
that those who were "divinely trained" needed no one to educate them (Nichol, 1966:77-78). The antagonism toward education by early Pentecostal leaders, as noted previously, was evidenced by their denunclation of Darwinism. Darwinism was considered a "false doctrine" composed of heretical teachings. The theory of evolution contradicted the members' belief in creation (Hollenweger, 1972:273, 296 and Synan, 1971:57). The leaders protested against such currents of thought as Darwinism because these kinds of intellectual notions disputed the tenets put forth by their falth and thereby posed a threat to their "old-time religion" (Synan, $1971: 57-58)$.

Despite early leaders' protest against intellectualism, as the Pentecostal movement grew the attitude toward education changed. Administrators of the movement realized that the movements' adherents and youth were advancing through life without any training in Pentecostal-Christian principles. Consequently, Bible institutes, Bible colleges, and liberal arts colleges were organized by varlous Pentecostal denominations (N1chol, 1966:213-232).

One of the first Bible schools, Bethel Bible College, was established by the Reverend Charles Fox Parham in Topeka, Kansas in 1900. Parham imposed no tuition, the school was run on the "fa1th" polley that "...God would provide all material requirements through the freewill, unsolicited gifts of interested Christians (Nichol, 1966: 27)." Due to harsh criticisms advanced by established 
churches and unfavorable publicity generated by newspapers, Parham was later forced to close Bethel Bible College (Nichol, 1966:29 and Synan, 1971:103).

Several years later, in 1905, Parham moved to Houston, Texas and established another Bible school, "The Bible Training School," for the dissemination of his views. The Texas school was fashioned after the one he had organized in Topeka. The school again charged no tuition; it was run on the "faith" policy. The students were required to help in performing the tasks necessary to maintain the institution. The Bible was the only text and Parham was the only teacher. The Bible Training school operated only a few months before closing (Nichol, 1966:31-32 and Synan, 1971:103).

As occupation with controversy and schism within the Pentecostal movement during the period of 1914-1919 decreased, the various Pentecostal groups entered a period of institutional growth which was to last till the present. The development of Pentecostalism into a worldwide organization of churches brought about a new era of Bible schools and colleges to minister to the movement. More institutions included the following: Lee College, the first denominationally owned school, was established in 1918 by the Church of God of Cleveland, Tennessee; Emmanuel College, founded in 1919, was organized by the Pentecostal Holiness Church in Franklin Springs, Georgia; Central Bible Institute, the Assemblies of God's first denominational institution, was 
founded in Springfield, Missouri, in 1922 and; the same denomination also established its first liberal arts college, Evangel College, in Springfleld, in 1955 (Synan, 1971:209, 222).

One other institution which seemed to hold promise for the future of Pentecostalism was Oral Roberts University in Tulsa, Oklahoma. The school was founded by Oral Roberts and $R$. O. Corvin and advertised itself as the first unequivocally Pentecostal university in the United States. This educational facility started classes in 1965 "... with plans for a hundred-million-dollar campus that would house a first-rate university, offering, in time, doctoral programs in several fields (Synan, 1971:210)." Shortly after the dedication of the school, however, Roberts stunned the religious world by joining the Methodist Church. Although a great deal of Roberts' support in his early days had come from Pentecostals, by the $1960^{\circ} \mathrm{s}$, a greater portion of his income came from members of the more established or traditional churches. Roberts' desertion of the Pentecostal movement shattered the dream of his university becoming an educational center for the Pentecostal world (Synan, 1971: 210).

Despite the disappointment over the Oral Roberts University situation, by 1970 Pentecostal churches had established dozens of Bible colleges and other educational facilities (Synan, 1971:222). The fact that the pioneer leaders of the Pentecostal movement incorporated several 
preachers with no educational training, but talents vital to their work, was a unique instance which did not suffice as a justification for inadequate training (Hollenweger, 1972: 472). In order to provide people with proper training and to help them and others gain an understanding of the beliefs and practices peculiar to the Pentecostal movement, various Pentecostal denominations established educational institutions throughout the nation.

Turning to the Church of God of Cleveland, Tennessee, one finds that the need for education of the beliefs and practices specific to this denomination was created by the fanaticism which had gradually entered the movement and had continued untapered (Conn, 1955:44). The fanaticism had continued unabated and increased the church's vulnerability to the "false teachers" who penetrated the denomination. It is recorded that the Church was unprotected against "false teachers" because the Church structure lacked any form of government. With this conclusion, measures were taken to remedy the shortcoming in the Church system. The Church reorganized in May, 1902, with a simple design of government to protect the group from future intruders (Conn, 1955:4445). Having taken steps to safeguard the group against future exposure to heresy, the Church of God went to work to provide guidance to its members as to the beliefs and practices particular to the denomination.

During the first year after the reorganization of the Church of God of Cleveland, Tennessee, an important change 
took place in the worship services in response to the misdirection and misdevotion which had occurred.

Teaching became a prominent part of the meetings, and there were many gatherings where the scriptures were discussea by the entire group. This gave opportunity for instruction in vital issues pertinent to individual needs. These sessions were an outcropping of their determination that no future rampaEe of fanaticism would catch them unprepared. In the past when great crowds were present, the services had been evangelistic to the neglect of thorough pastoral teaching. Basic instructions in the Pentecostal faith had seemed sufficient, but now, ...more serious study of the Scriptures became much in evidence (Conn, 1955:48-49).

The response to the fanaticism which had infiltrated its structure provided the denomination's adherents with an opportunity to better understand the beliefs and practices specific to the Church of God. This helped the group to achieve a better balance of doctrinal comprehension and evangelistic fervor (Conn, 1955:49).

Later the Church of God, established several educational facilities which served to assist in the comprehension of its tenets and practices and to train members for efficient service in the local communities. The Church of God furnished 1ts members in the United States with both junior college and Blble college institutions at Lee College in Cleveland, Tennessee, West Coast Bible College at Fresno, California, and Northwest Bible College in Minot, North Dakota (N1chol, 1966:101). Of these three educational institutions, Lee College is probably the best known. 
Lee College, so named after one of the most wellknown General Overseers of the Church of God of Cleveland, Tennessee, F. J. Lee, was the first denominationally owned college. The Church of God organized the school in 1918 (Synan, 1971:209, 222). The more gifted of the college's students can earn a bachelor's degree in "...'biblical education,' 'church music,' 'Christian education,' and 'combined areas of Bible and music' (Hollenweger, 1972:51)." Lastly, aside from teachings at worship services and studies at educational facilities, the Church of God hoped to help its members gain an understanding of its doctrine and rituals by adopting a more systematic organization of its Sunday Schools. The delegates at the Annual Assembly of 1928 decided that every state should have a "State Sunday School Convention" and a "District Sunday School Convention" and further, that each state provide a state superintendent of Sunday Schools and a superintendent of Sunday Schools for each district within the state. The Church's more efficient organization of its Sunday Schools is reported to have "...made the work of Christian education more widespread, and 1ts program more effective (Conn, 1955:206)."

In summary, the Church of God of Cleveland, Tennessee, has tried by a number of means to help as many of its members as possible to gain an understanding of its tenets and practices. Such means include teachings at worship services, studies at colleges like Lee College, and employment of a more systematic organization of its Sunday Schools in 
order to educate a greater number of people, using a more effective program. Overall, the denomination has provided a variety of means to educate its members as to its doctrine and practices.

\section{Experience}

Religious experience is the dimension of religious commltment which considers the notion that religious groups expect "properly" relıgious people, at some time, to attain some kind of communication, some sense of contact, with a supernatural agency. Such contacts or experiences provide for a diverse grouping of events ranging from vague or fleeting contacts to "rapturous mystical" encounters with some divine essence. Assuredly, rellgions vary as to the type and degree of experience considered "proper" in their respective traditions. Nevertheless, a personal religious experience, in any religion, is accredited some value as an indication of individual religlousness (Stark and Glock, $1968: 15,125-126)$.

Pentecostalism, throughout 1ts history has placed great emphasis on Individuals' conscious religious exper1ences. Beginning with Methodism, empirlcal evidence of salvation $1 \mathrm{~s}$ what John Wesley and his adherents sought to present to the world. Next, the doctrine of holiness, which was common to all Pentecostal groups, was essentlally a matter of religious experience. The harshness of Pentecostal dally living served as a means for securing and retaining a religious experience or as a demonstration of their falth 
In the power of an experience. Furthermore, it has been reported that the early Pentecostals stressed a religious experience rather than a system of doctrine or church admin1stration (Boisen, 1955:77; Nichols, 1966:55; Synan, $1971: 14)$.

Two of the first religlous experiences stressed by early Pentecostals stemmed from John Wesley's theology which molded the Methodist movement. Wesley's notions on theology included two distinct phases of experience for the believer: the first, conversion or justification, and the second, Christian perfection, or sanctification. In the flrst encounter, the repenter was forgiven for the sins he/ she committed, became a Christian, but still held a remnant of sin within. This remalning sin was the outcome of Adam's misfortune and had to be treated by a "second blessing," known as sanctification. This cleansed the bellever of "Inward sin" and presented him/her with "perfect love" toward God and fellow bellevers. Wesley taught a perfection of motives and desires, not a perfection which would be sinless. The followers of Wesley's teachings sought his proposed perfection through the "double cure" of conversion and sanct1f1cation (Synan, 1971:18, 32).

Later, a third experience, separate from and following sanctification, was taught by Benjamin Hardin Irwin and was promoted by Charles Fox Parham. Irwin's 1dea was that the baptism of the Holy Ghost was an experience distinct from and subsequent to sanctiflcation (Synan, 1971:68). 
The experience involves the idea that a Christian can achieve "full holiness" or "entire sanctification" only when "...he abandons all efforts and allows the Holy Spirit to live within him the life of Christ.' When the Spirit makes His abode within, it will be manifested by the bellever's experiencing a definite emotional reaction. This is his baptism in the Spirit... (Nichol, 1966:6)."

The "definite emotional reaction" which became, for Pentecostals, the evidence of the baptism of the Holy Ghost was the phenomenon of speaking with tongues or glossolalia. The first time the experience of glossolalia was assoclated with the experlence of being baptized or filled with the Holy Ghost as the physlcal evidence appears to be at the Topeka revival led by Parham (Menzies, 1971:39). The event at the revival was described as follows:

...Parham and his students conducted a watchnight service on December 31, 1900, which was to continue into the new year. In this service, a student named Agnes N. Ozman requested Parham to lay hands on her head and pray for her to be baptized with the Holy Ghost with the evidence of speaking in tongues. It was after midnight and the first day of the twentleth century when Miss Ozman began 'speaking in the Chinese language' while a "halo seemed to surround her head and face.' ...After Ozman experienced 'tongues' the rest of the students sought and recelved the same experience. Somewhat later Parham himself recelved the experlence and began to preach it in all his services (Synan, 1971:101-102).

The signiflcance of these events in Topeka, Kansas was that for the first time the theme of being filled with the 
Holy Ghost was connected to an external indication speaking in tongues. From this point on for the Pentecostals, the evidence, the physical manifestation, that believers had been baptized with the Holy Ghost was that they could comminicate in other tongues (Nichol, 1966:28).

The experience of being baptized with the Holy Ghost, evidenced by sieaking in tongues, was also widely acclaimed at the Azusa St:eet revival in California in 1906. There a multitude of people "fell under the power" and began to speak in other tongues (Nichol, 1966:33 and Synan, 1971:107). Scores of people went to Azusa Street expecting spiritual help, and through the supernatural encounter of "baptism" indlcated by glossolalia and reportedly, in some inexplicable way, they recelved the help (N1chol, 1966:34).

Although the experlence of speaking in tongues received great attention at both the Topeka and Azusa Street revivals, it should again be noted that the phenomenon was not a Pentecostal innovation. In one form or another glossolalia has shown itself throughout the history of the Christian Church. As records have indicated, many periods of Christian history have been frequented by sporadic outbursts of glossolalia (N1chol, 1966:19 and Synan, 1971:119). Therefore, the outbreaks of tongues at Topeka and Azusa Street were recurrences of an acknowledged Christian phenomenon. In the Pentecostal tradition, however, this phenomenon represented a "repeatable and unmistakable motor expression" which acted as physical evidence, as a guarantee, 
that the believer was filled with the Spirit (Synan, 1971: 122).

Assuredly, in Pentecostalism, speaking in tongues probably has been the most recognized experience or evidence of one's baptism with the Holy Ghost. Nonetheless, other Indications also have been considered by Pentecostals to be signs of "possession" by the Holy Ghost. Such indications Include "... Interpretation of tongues, the 'holy dance," the 'holy laugh,' and the 'laying on of hands' ror divine healing (Synan, 1971:187-188)." These experiences, along with speaking in tongues, have provided Pentecostal believers with more than the mystical presence of God. They have exhibited the physical presence of the supreme being as well, making $1 t$ real and accessible to the "common man' (Menzies, $1971: 27)$.

In essence, therefore, the experiences presently discussed serve as physical manifestations which represent some sense of contact between a Pentecostal believer and God. The religious experiences, for the most part, take the form of motor phenomena and in some cases, for example, the "holy dance" or glossolalia, the behavior exhibited cannot begin to be explained by outside observers. Such unexplicable expertences have not and do not concern Pentecostal members. Pentecostals "...to find themselves doing things they can't account for is for them the all sufficlent evidence of control by the Holy Spirit (Boisen, 1955:91)." In sum, experiences such as glossolalia, divine 
healing, and the "holy dance," which evidence one's baptism with the Holy Spirit, represent some of the personal religlous experiences which the Pentecostal movement has valued as signs of its members' religlousness throughout its history.

Looking at the particular Pentecostal denomination of the Church of God of Cleveland, Tennessee, one flinds that the religious experiences valued as indications of members' religiousness are essentially the same as those valued by the Pentecostal movement in general. That is, throughout the history of the Church of God, the experiences of conversion, sanctification, baptism with the Holy Ghost evidenced by glossolalia, and divine healing have been considered subjective religious experiences, individual encounters with God, valued as signs of religiousness. The Church of God, before it was known as such, flist realized the experiences at a revival at Schearer Schoolhouse at Camp Creek in Cherokee County, North Carolina in 1892.

Aslde from the reportedly hundreds of people who were converted and filled with the Holy Spirit at the Camp Creek revival, many affilcted people experienced divine healing. Unfortunately, the diseases and illnesses that were remedied were not recorded in any written fashion, but the healings which took place are said to have been "miraculous" (Conn, 1955:27). Divine healing was another experience, another kind of personal communication between a believer and a supernatural agency - God, which was valued by the 
Church of God as an indication of that believer's religiousness.

So, the Church of God of Cleveland, the oldest of the Pentecostal denominations - 1ts existence dating from 1886 did not have any sort of major display of religious experiences for the first ten years of its existence (Conn, 1955:xxii). Even at Camp Creek the Church's members did not fully understand the significance of the religious experiences they encountered, especially, the baptism with the Holy Ghost. The members saw in this experience only "supernatural foy" and "physical manifestation." With time, however, the experience "...would teach them, even before the Scriptures, that they had received infinitely more than joy. They were made partakers of ... - the Comforter - the Third Person of the triune of God (Conn, 1955:26)."

As the Church of God grew, religious experiences consistently appeared at such functions as revivals and annual assemblies. For example, many people who attended the Pleasant Grove revival in 1907 underwent conversion, many were healed, and a good number experienced the baptism with the Holy Ghost evidenced by speaking in tongues and other demonstrations such as interpretations of tongues, dancing, and trances (Conn, 1955:98). Also, at the Third Annual Assembly, which too took place in 1908, many people who were "demon-possessed" were converted, many afflicted persons experienced healing, and again, a good many recelved the Holy Ghost (Conn, 1955:91-92). 
While most annual assemblies displayed a variety of religlous experiences such as tongues, healing, baptism with the Holy Ghost and so forth, some assemblies emphasized or concentrated on but one experience. For example, the Assembly of 1924 (Nineteenth) focused on divine healing, reflecting the intenseness of the General Overseer, which was at that time W. J. Lee, on the subject. Each evening service of the Assembly was devoted to praying for the afflicted and reportediy, hundreds were healed (Conn, 1955: $136,195)$.

In sum, the history of the Church of God of Cleveland, Tennessee has disclosed various religious experiences. These experiences such as conversion, sanctification, baptism with the Holy Ghost evidenced by tongues, and divine healing, are a diverse set of evidences which represent for the Church a sense of personal communication with the divine essence of God. This sense of contact is valued by the Church as an indication of individual religlousness.

\section{Conclusion}

The present chapter has looked selectively at the historles of the Pentecostal movement in general and of the Church of God of Cleveland, Tennessee in particular. The historles focased on the natures of the1r religlous commitments. This emphasis serves to highlight the contexts likely to have influenced the local Pentecostal congregation's notion of religious commitment, as well as to demonstrate the utility of the soclological scheme of commitment 
suggested by Stark and Glock. The local Pentecostal group's native definition and interpretation of the nature of their religious commitment is the subject matter to which we shall next turn our attention. 


\section{CHAPTER III}

THE HIGHWAY CHURCH OF GOD:

A VIEW FROM THE INSIDE

Stark and Glock's (1968) method of examining the nature of religious commitment represents, in part, a ploneer attempt by social science researchers to decide just what religious commitment is. The basic conceptual scheme proposed entails a set of flve core dimensions of religiousness: belief, practice, knowledge, experlence, and consequences (Stark and Glock, 1968:14). This conceptual strategy was the focus in the previous chapter in the examination of the history of the Pentecostal movement in general and of the Church of God of Cleveland, Tennessee in particular. The application of Stark and Glock's conceptual system of the nature of religious commltment to the nature of religiousness exhibited throughout the history of these two religious movements was successful in that the information provided by the descriptive histories could, indeed, be examined in terms of the dimensions of religiousness proposed by the researchers.

The histories of the two religlous movements, however, were drawn in terms which represent only the physical or outward expression of events. The employment of Stark and Glock's definition of the nature of religious commitment to the descriptive histories of the religious movements results in a characterization of the empirically observable 
manifestations of the religious groups' nature of commitment. The question raised in this study, however, is what happens when one tries to use the conceptual scheme of religlousness suggested by Stark and Glock to examine a local Pentecostal congregation and its members' (the native or insiders') point of view of their religiosity.

In order to preserve the native viewpoint in this study, the method of triangulation was employed. Ethnosemantic interviews provided the principal source of data, while participant observation and survey data served as cross-checks and supplements to the interview data. Such a procedure aided in eliminating ambleuity and creating order out of the data gathered. The ethnosemantic interviews, in conjunction with participant observation and survey data, provided the means necessary to discover the cultural knowledge ut1lized by the members of a local Pentecostal group to interpret the nature of their religious commitment without distorting such knowledge. The insider's point of view was thereby preserved. The importance of preserving the insider's viewpoint lies in the conception that the insider's view of his/her actions and their meanings usually differs from others who may share similar behaviors and beliefs. As an insider, as a member of a particular group, one defines his/ her behaviors and beliefs differently (Spradley, 1979).

The result presented here is an ethnosemantic description which approaches the manner in which a particular congregation views the nature of their religious commitment. 
The cultural theme which surfaced repeatedly throughout the data gathered on the local group differed from the conceptual strategy of religlous comitment proposed by Stark and Glock (1968). Instead of categorizing their religious commitment In terms of belief, practice, knowledge, experience, and consequences, the conceptual framework of the Pentecostal natives entailed only two dimensions - the physical and the spiritual. In other words, by preserving language the members of the local congregation used in talking about their religion, I discovered that the nature of religious commitment, as viewed by insiders, was substantially different from the scheme proposed by Stark and Glock (1968). These differences and their ramifications are explored below.

The inftial indication of the congregation's conceptual scheme surfaced in a discussion with my primary informant, the pastor, on worship:

The outward manifestation of worship is what you would equate with the physical end of it where the spiritual end of it comes from within. In

Revelations we see the Splrit of God is talking to the churches and He talks to one of the churches saying that He knows about them and He knows that they have a form of religion but they deny the power thereof. Again, it equates to having all the outward form and ritual and procedures down pat but actually lacking the most important ingredient, and that is a heart or the true meaning of religion is not, again, not in any form.

This Idea of the true meaning of religion not existing in any physical form was reiterated by my informant in a discussion concerning God and religion: 
...I guess really when you're talking about God or religion, there are basically, there's the physical and there's the spiritual. Even in the word of God it brings out, it says "The flesh is against the spirit; the spirit against the flesh continuously." They are two powers, two remains - there is the physical and there is the spiritual. It should be stressed in our worship, our public worship, even in our private worship, is the spiritual end because the physical end of it is really unimportant. It's unimportant in the eyes of God because the Word says that, "Your righteousness is but fllthy rags unto the Lord." So it doesn't really matter if we wear a three piece suit; it doesn't really matter if our hair is in place or my mustache is trimmed. The important thing is that we are seeking the Lord the way He wants us to seek Him, and that is in a spiritual sense. The Lord was speaking to a woman at the well, Samaria. She was saying, "Well, some say we should go to Jerusalem to worship God, some say we should go to Samaria, Mt. Carmel or some other mountain;" and Jesus said, "The Irord seekest us to worship" - He was talking about those who would come to Him in spirit and in truth. So, that's out of the mouth of the Lord, He's saying, it's more important to seek Him in Spirit and in truth than it is to seek Him in any particular place or in any particular form.

The informant went on to point out that despite the insigniflcance of form, it still exists. Form remains because human beings can not live without it. The form which exists, however, does not come about haphazardiy; there has to be a constant searching to arrive at a form which w1ll please God.

And that is when our physical world 1 s channeled to a spiritual fulfillment, instead of our physical world channeled to a physical fulfiliment.

In sum, the conceptual scheme of the physical and the spiritual dimensions of religion was recapitulated by the informant in the following sentence: 
...the physical takes care of the body and surroundings, and the spiritual aspect is the Lord and the things of the Lord.

The notion of the physical and splritual elements found to compose the local congregation's viewpoint of the nature of their religious commitment is not an abstract phenomenon. These dimensions organize, inform, and interpret their actual religious experiences. The employment of this cultural theme was demonstrated in a discussion concerning "living Pentecostal."

...there's two ways of answering. There is the way that the laity see Pentecost; there 1s the way 1t really is. Many people in Pentecostal churches, as far as the laity is concerned, equate Pentecostalism with the very outward show of spirltuality. You know like, whenever you meet somebody it's, "Praise the Lord!" - 1t's an outward expression of something that you have inside. So many people in the Pentecostal denomination tend to sometimes concentrate more on the outward mannerisms or conduct, per se, where the real heart of Pentecostalism, I belleve, really has its roots in hollness. You can fake a lot of things. You can fake sincerity, you can make it seem that you're sincere about something, or you can also fake Pentecostal worship, too. You can be in a congregation for a period of time and never really fulfill the true meanlng of Pentecostalism because you wind up dolng the mechanles than the Lord actually dealing through you. It's really a state of holiness. In other words, a true Pentecostal person is a person that is holy, not a person who is plous, not a person that is self righteous. But a person that doesn't lie at all. Doesn't talk badly about someone else. The Bible says "if you can't say anything good then keep your mouth shut." A truly Pentecostal person will be that because the attributes that Christ had are perfect attributes. He had the "fuliness of the spirit," the Blble tell us, and He had "perfect patience," "perfect compassion." It says, "He walked by, He had compassion for certain people," and in studying some of these Scriptures, it actually meant that 
He could walk by people and actually feel their physical pain. In other words, if $\mathrm{He}$ met someone whose hand was chopped off, He could actually feel the pain in his arm, - sympathetic type thing. He was so attuned to other peoples needs, He really felt these things. And if we allow ourselves to really achleve a close relationship with the Christ, which is what we're all supposed to be dolng in this Christian religion, then 1t should automatically come about that we would take on the attributes of the one we are trying to get close to. If you are truly seeking to be Christ-like, then 1t's not in anything you say, 1t's not anything you do - some people walk up to me and say, "Pralse the Lord!," and smlle, and 1t makes me slck. Because you know, I don't feel anything coming from within at all. And some people can get up and lead song service and it doesn't do anything. Because Pentecostal living really is something that is more felt than seen.

The Informant again went on to support the conception that Pentecostal living is a phenomenon more felt than observed by citing Scripture which, for him, proved his polnt:

...1t's an Inner something. The Bible talks about the spirit of God bearing witness one with another. It's true, sometimes, I w1ll meet someone that I have heard about for maybe a long perlod of time and I expect to almost shake hands with a really salntly, dynamic, overwhelming, awe-inspiring person, you know, and I shake hands with that person and I have no feeling spiritually about the person. And then I'll shake hands with someone who nobody has even introduced me (to) - and I find love radiating from that person. Not only women, but both men and women al1ke. It's something that just comes out. It's true that the word of God talks about this too. It says that the people who were with Chrlst, the other people knew just by walking by - they knew these people were with christ. It wasn't necessarily by their verbal statement. It was by the spirit. They felt the communion of the spirits between the disciples of Christ Just as they walked by and that's what told them they were in league with Christ. It wasn't necessarily an outward manner or an act. 
The native view of Pentecostalism as something more felt than observed, as something more spiritual than physical, is an 1dea which occurs on an individual level. This same framework, however, aside from existing on an Individual or private level, also presents itself in a public domain in a shared cultural scene, as native knowledge used to organize and interpret the members' behavior. The public domain includes the acting out of different types of worship services and the assorted occurrence of events at church services. These phenomena, again, transpire according to the "will of the Spirit." For this congregation that is what is more important. The actual physical manifestations of the phenomena which are readily observable to non-members or outsiders are simply overshadowed by the spiritual dimension. This relationship between physical and spiritual can be observed in a number of particular episodes at the Highway Church of God.*

\section{Worship Services}

The first phenomenon I will examine are the incidences of different types of worship services which result "at the discretion of the Spirit."

That's part of Pentecostal worship - is letting God have His way in service...

...services are every so often quiet and soft because they're soul-searching, to the point

\footnotetext{
*The Highway Church of God is the pseudonym given to the congregation studied in order to preserve its anonymity. The name will be used from this point on to refer to the local group.
} 
where sometimes even before the service gets on, there's an altar call, and we're drawn to the altar to pray and to cry and whatever we need to do to just humble ourselves. The Bible says "we are to humble ourselves before God" - not to walk into the house of God and say I am Mr. Perfect and just sit down there nice and feel that everything is for everybody else.

The quiet nature of some services, according to my primary informant, however, often seems out of character for Pentecostal services. As we have seen, people have come to regard Pentecostal services as dynamic, exclting, and emotional. This "outsider view" is acknowledged:

Many people equate certain things with Pentecost. If you go to a service that is very quiet, very serene, people would probably put it down as far asI guess some people sometimes go there to enjoy themselves. They enjoy the excltement of getting themselves involved. But that's not really Pentecost. Pentecost can be that but sometimes we have some very quiet sort of services.

So, one type of worship service resulting from the will of the spirit is the quiet service. The informant went on to describe the type of Pentecostal service expected by many people - the joyfull or happy worship service:

But the services - there are all types, but most Pentecostal people, again, are geared to the happy side - the enfoyment. And there's nothing wrong with that; you have to have a balance; you have to have - you know, there are people all they want to do is sing and enfoy themselves. The joy of the Lord is our strength. I can show you scripture upon Scripture that say that we, as Christians, are suppose to have a joy in us - just to be thankful about so many things. If you really are (thankful), then you really can't shut up. You have to 
express that love but you can go off too far, you can get wrapped up in emotionalism. And Pentecostal worship does have emotion in it but it should never be just emotion.

The notion that the nature of Pentecostal worship should not always be one of only emotion was expanded upon in further discussion. In describing circumstances under which the members of the local congregation or any Pentecostal group may be led by the Splrit to participate in a service of emotional character, my informant remarked:

And sometimes we fust get wrapped up in the emotion of it. Let's face it with the world system the way it is, the economic system the way it is, the pressures of recession - everything, and according to Scripture, I believe that all these things are going to get worse. People want to wipe out everything that's out there and they want to get wrapped up in the blessings of God. Sometimes, belleve me, I feel like just letting go. People need to have something that's positive. And nothing that would be destructive like shooting cocalne. As a pastor I try to be in tune. Sometimes we just need to praise God; just enjoy the joy that we have. But then never to get to the point where you always lean that way and are not willing to be quiet before the Lord and be humble before the Lord.

In sum, the informant described Pentecostal worship services of two natures: quiet; and emotional or joyful. The discussion of these types of services, however, was not only based on his personal experience. In addition, scriptural authority was invoked: "where in the Word of God It says we are to humble ourselves before cod" or "that we, as Christians, are suppose to have a joy in us." The informant's preference for one of these services was not 
based on some personal wh1m, but on h1s authority - on the Word of God which discloses that members are to be quiet and/or joyful in their worship depending on which way the Spirlt leads them. Indeed, over the course of several visits to Sunday worship services at the Highway Church, I observed some services which were quiet and serene in nature and others which were much more emotional or effusive in character. Further, as the informant pointed out, I was one of those people who had always equated emotion and excitement with Pentecostal1sm and who, at first anyway, found herself disappointed when the services were not always dynamic in nature.

\section{Nonrout1ne Worship}

During the numerous worship services I attended as a participant observer, several events occurred routinely: singing, praylng, giving of an offering and giving of testimony by at least one member. There were other events, however, wh1ch did not take place at every serv1ce I attended. For Instance, altar calls, speaking in tongues, and interpretation of tongues were events which were not evident at every Sunday service. The nonroutine character of worship services was explained by my informant.

In this book here of the Bible Institute, (it shows that) men are very good at one thing, setting down rules and formulas for almost anything and everything. In here they have a formula for what a service should be. There is an open1ng, a song service, there is not, per se, a reclpe as far as going blank, blank, blank, but what they're saying in their book is basically what is involved in worship. They've given 
maybe five, six or seven different aspects of worship. Our giving of our money is worship, it's part of the worship thing and it should be undertaken in that aspect. It shouldn't be, "Okay, now it's time to fork over the cabbage." But it should be undertaken in a manner as 1t really should be. It's a privilege, it really is, and it's a form, (a) part, it's an integral part of the worship service... So, in here it gives you five or six different things that should be involved in worship service. One, again, is the glving, one is testimony service, one is again, prayer. It makes sense that we should pray, makes sense that we should have an offering, it makes sense that we should sing us a hymn or makes sense that we should have the word of God preached and all these other things they have in here also. Then again, it is not necessary to have all of them. You can have aIl of those or none of the above and God can still be pleased with 1t. Sometimes you can go into the house of God, Iike I do sometimes, when there's nobody else there and I have a worship service. And sometimes I'll calI up a brother from Norwlch or we'll go up to his church, and we don't have these other things that the book says you gotta have but yet we have worship service.

The informer went on to express his concern regarding the presence of events merely for the sake of conformity or ritual and not as the result of the leading of the Spirit of God.

Even Pentecostal churches which people equate with freedom and looseness and expression seem to be falling into even a form or an outline type of worship service type thing. I don't want to do anything for the sake of ritual, for the sake of conformity; I don't want to be a conformist; I don't want to be a nonconformist. I want to be whatever God wants me to be at that particular time... I place a high priority, in fact, the highest priority, on what I feel the spirit of God wants at any particular time. If you were in a pew and I felt checked in my spirit that there was something that you needed, I would stop everything that I'm doing and go and take care of that need, if that was something that was revealed to me through a spiritual channel. 
This expressed wlllingness to "stop everything and take care of a need" was not an idle expression. When asked for examples, the informant, claiming there were many, gave two "off the top of his head." The first instance involved an episode in which the informant had been asked to flll in for a day, for a pastor at another church. The evening service at the church exhibited a mixture of "some special singing and prayer" and testimonies. Brothers and Sisters were testifying, one after another, "of the goodness of the Lord and how the Lord had moved in their lives in different ways." The continuous testifying "became in itself a worship." The informant kept watching the clock and started to think in his "natural mind,"

"This has got to stop, this has to come to an end because the Word of God has got to be preached." And the natural mind, you know,... you try to put everything into nice little cubicles and order everything $1,2,3,4$, and it was coming about that way too. "When - how am I going to cut it off?" (And then) it was just as if I got a telegram and it said, "You don't cut it off, you must let it go because this is what the people need."

The "telegram," in this case, was sent from the Spirit of God. The service took on a character different from that which was planned because services are supposed to be "led by the spirit and if you're not careful you can quench the spirit."

The Bible says that "we're not supposed to quench the Spirit." That's what I belleve 
the Scripture is saying. When we come together to worship we need to let the Spirit of God lead and guide us.

This notion of services being "Spirit led" was acted upon at the evening service described by my informant.

...at some particular time there was a desperate need of prayer. We prayed from that time of the service on. It was completely different because we felt and sensed the need in the Spirit, and then we answered that need.

A second example which exemplifies the willingness to "stop everything and take care of a need" Involved a time when my informant was a preacher in another town. During a service, whlle delivering his "message," the informant received "a distinct thing like, 'Go down and pray for this fellow." The informant fought the notion and continued with his message - a message he felt very strongly the Lord wanted him to speak about; he was sure about it. About five minutes further into the message, however, he got this feeling again, "Go down and pray for this fellow." The informer could not get this feeling "out of his being."

...I felt I would never be able to get done what the message was until I did what God wanted me to do. The thought came into my mind, "Three strikes and you're out." And it's funny the things that come into your mind, you'd think a spiritual person would have big high level things - but the Lord talks to me in very simplistic ways. But I said, "No, I don't want to strike out." so I just anointed the fellow and I prayed; and to this day I don't know the outcome of that but you see it's not for me to know; it's for me to feel the need. 
The ability to "feel the need," agaln, results from being "in tune" with the spirit.

These examples display quite clearly the Highway Church's notion that the nonroutine occurrence of events at worship services 1 s the result of the leading of the Spirit of God. The events which do or do not occur at a service derlve from the guidance of the spirit and not from a formula in a book. The incidents of a service are revealed to the members through a spiritual channel and not through a ritualistic formula. In sum, whether the focus of the public domain is on the acting out of different types of worship services - quiet or emotional - or on the assorted occurrence of events at worship services, the domination of the "spirit" 1s evident.

Pentecostal churches, again, are suppose to be churches that are Spirit-led and run. Really, the way I see 1t, 1t's the splritual end that really is the predominant part of worship. The Blble tells me that we must come to Him in spirit and in truth, not in any particular way, or manner, or form, or ritual.

\section{The Role of Scripture and Knowledge}

The ability of the informant to cite Scripture which "proves" the point he 1s making frequently presents 1tself. Throughout discussions of varlous phenomena, the Informant repeatedly specifled Scriptures which bolster his case that he is not acting on his own accord but that his actions are based on an authorlty, the Word of God. 
The first thing that we believe and the people have to accept is that the Bible is infallible. It is the Word of God, and whether we agree or disagree with anything in it, we have to accept it. To successfully make a commitment to christ, you have to believe that; otherwise, all the scriptures that talk about God, Christ, and what have you, have no effect.

Despite the fact that my informant was capable of reciting Scripture time and time again to support the notion that religious commitment has physical and splritual dimensions, he denied that the amount of knowledge one has is 1mportant. Indeed, he claimed that he did not possess a great deal of knowledge.

So knowledge is not really important, per se, the amount of knowledge that you have, it's the major ingredient that's important. I don't. have a lot of knowledge; I wished that I had, a lot of times. But then, I feel in my own way, that I have a lot more than what a lot of ministers have. Many ministers have the knowledge up here (pointing to his head) but they don't have the knowledge down here (pointing to his heart). I have most of my knowledge here (heart) and a little bit up here (head). That's okay. I'm very self conscious about that at times. I put myself down about that a lot of times. I'm not a big person as far as knowledge, per se. I know people who could scrlptually, run circles around me and quote. I can't quote scripture like a lot of people can.

The informant's admission of his inability to quote Scripture, one right after another, did not signify that "he can't do 1t," per se, but that he "can't do it the way he'd like to right now because his time is limited." Still, he was unconcerned about the matter. 
But the thing is, I don't care that I can't do that right now because I still know that whom I belleve in. That's a Scripture too - "I know whom I believe in and I am persuaded He is able to keep that which I have committed unto Him against that day." That scripture tells me that as long as I know Him and as long as I commit myself to Him, it doesn't matter what I know, everything else, as long as I know Him. This is the way I always felt about knowledge.

The informant went on to note that when people begin to discuss religion and talk about different aspects of heaven, the new Jerusalem, and other subjects, when they recite "ten thousand facts" they have "memorized" about the various topics, he finds it "Irrelevant."

It's ridiculous; that's the way I feel. I'm not putting down the people who want to do somethir.. like that but you see a lot of people get so bent out of shape with knowledge that they lose Jesus Christ. They get so fizled with extraneous things...

In sum, my informant's impression of knowledge is captured in the following sentence:

It's good and everyone should strive for more but make sure you have the warmth, the important knowledge that is needed.

An interesting dilemma presents itself in my informant's discussion of knowledge. In his critique of knowledge, the Informant appeared to refer to two different types of knowledge: knowledge in a formal educational sense and knowledge in an inner splritual sense. The former was Indicated by such references as: "knowledge up here (pointIng to his head);" "conjecture;" "memorize;" "people get so 
bent out of shape w1th knowledge that they lose (the knowledge of) Jesus Christ;" "extraneous things;" and "frsts." This "knowledge up here" was not highly regarded: "knowledge is not really 1mportant, per se, the amount of knowledge that you have;" "irrelevant;" "ridlculous;" and "...never lead you to Christ." The other sense of knowledge, that of an inner spiritual nature, was signified by such references as: "the knowledge down here (pointing to his heart);" "I still know whom I believe in;" "all I know is I want to be there (in Heaven);" "they lose (the knowledge of) Jesus Christ;" and "make sure you have the warmth." The "knowledge down here" was evaluated in one phrase, "the 1mportant knowledge that is needed."

So, the informant's denial of the importance of the quant1ty of knowledge possessed is really not the issue in this instance. Rather, his concern $1 \mathrm{~s}$ the type of knowledge possessed. Again, the cultural scheme of the Highway Church, the conceptual strategy of physical and spiritual, appears to present itself. The type of knowledge held and deemed important by the informant is that of an inner spiritual nature, "knowledge of the heart," which 1 s more felt than seen. Knowledge of a formal nature takes on the physical dimension of the native scheme in that it represents the outward manifestation of "facts" which people have "up here." The Scriptures quoted by the informer do 1llustrate knowledge representing the physical dimension of the cultural scheme, but such knowledge is only a means used to demonstrate the 
origin of his spiritual knowledge. In other words, the Scripture quoted by the informant represents the observable, unerring knowledge used to show the origin of his more Important, spiritual knowledge. To put it another way, the Scriptures quoted, represent as best they can, the physical or outward manifestation of the spiritual knowledge possessed by the inforiant. That "heart knowledge" is more felt than observed, and is also considered more important than the "head knowledge" which is readily perceivable by an outsider.

The "head knowledge" portrayed by the histories of the Pentecostal movement and the Church of God was also deemed less Important than "heart knowledge." The informant's opinion regarding this matter was quick to come to light.

Now, I'll give you a quick history of the Church of God - very quick because I've never really studied it in depth, just read here and there. I didn't get called to the ministry to bring forth the propagation of the Church of God. I came here to bring forth Jesus Christ. I don't study the Church of God. I don't study what happened to them but being in the organization you do pick up different articles...

This statement when coupled with the fact that the informant rarely volunteered historical description of the religious movements in any context, served to indicate what little value is placed on "head knowledge;" in turn, suggesting that the likelihood of the religious histories influencing the Highway Church's notion of religious commitment is not as probable as was projected in the previous chapter. As a matter of fact, in this instance the religious histories 
appear to have had IIttle Influence on the Highway Church's view of religious commitment.

Thus, at this point in the investigation, the local congregation's conceptual scheme of the nature of their religlous commitment and even their knowledge is clearly organized along two dimensions, the physical and the spiritual, with the latter considered by the group to be the more important of the two dimensions. The native conceptual strategy was testifled to in several conversations which entertained a variety of topics including: worship, God and religion, what is involved for someone who lives Pentecost, the acting out of different types of worshlp services, the nonroutine church services, and the knowledge which pertained to these various topics. In addition to these general features, the conceptual strategy of the Highway Church is acted out in four specfic events: "hitting the altar," "hitting the floor (being slain in the spirit)" "giving testimony," and "confirmation from God."

\section{Hitting the Altar}

What the event of "hitting the altar" entails is described in the following account:

What Scripture comes to my mind in reference to that is "Ask and thou shalt recelve, seek and ye shall find, knock and ye shall be opened unto you." I don't know all your needs - physically, mentally, financlally. You may be willing to express them to me, in confldence that I might pray with you and agree with you. According to God's work; that we agree on anything then we have what we petition the Father if we truly believe in falth we pray that prayer. But there are times, 
and there are always times in everyone of our lives there are things you would not want to share with anyone and it's right. It should be between you and God. But there are times when I can sense that you need to ask. Sometimes you might be led...I feel in my spirit that there is a need for prayer... So when I feel someone is in dire need - just one person, doesn't have to be everybody - as long as one person has that need, I believe we need to all be as of one accord for that person.

The informant proceeded to "prove" his belief that strength lies in numbers by, again, quoting his authority.

...the Bible says "Cease not to lift up one another in the most holy of faith, pray without ceasing. Peter was prayed for in the story about when he was in prison, and the congregation gathered together and they prayed, prayed all night long. Peter got the spirit, broke him out of jail, he walked all the way up to where they were. This is where there is a need sensed.

A person with a need can also acknowledge that need on their own free will if the spirit leads them to do so.

I feel my job, what God wants me to do with the people there, or anywhere that I minister, is to get people to a point where they're willing to move when God says move. I don't care, whether it's the song service, testifying, I don't care If I'm preaching, I don't care what happens at any time if someone is led that they ought to go up there to the altar. It's right for them to go up there.

In sum, an altar call occurs when

I feel there is the need or when someone admits by their own move they need to hit the altar. 
From this description, hitting the altar entails elther a perception by one person that another has a need or that person admits on their own accord, by their move to the altar, that they have a need. Once the move to the altar occurs,

\begin{abstract}
Now at that particular time I would do one of two things. I would either ask - belng now there is another minister there - I have a little more leeway (than) if there wasn't another minister there. Because I do have a minister there working under me, I can motion to him, if I feel that's the way it should be done - pray for him, further. Or, again, it depends on that instant like that (snaps flngers), whether we stor everything and both of us pray or I pray or 1t's happened at times that the whole church would come down and pray for that particular person and/or themselves. Usually, this is what happens, when we get down there to the altar, maybe to pray for a particular thing, we don't all go back and sit down. We're already down at the altar, we've already prayed for a particular need, while we're there, we might just as well take care of every other need and let's face it, not one of us is perfected yet.
\end{abstract}

The notion that "none of us are perfected yet" and, therefore, that all have needs to be prayed for is shown In the informant's admission of hitting the altar whenever the altar is opened up to a congregation.

Everytime I go into a service somewhere, minister or not, whenever the altar is opened up, I feel I got to be down there. Now, again, some ministers would say that I do wrong by dolng that. People look at me as a pastor and a minlster and say why is he golng up there, he must be sinning. I don't care - I want to humble myself before God. I want to be more used by God and I realize there's only one wey that's golng to be, if I admit to God at any opportunity that I can, that I'm nothing. 
A lot of times when I do go to the altar, it is not necessarily that I feel sin weighing down upon me - it shouldn't be just in a minister, it shouldn't be in any christian. Not that the weights of sin shouldn't be upon them but imperfections of character, things that if you ask someone, what are you hitting the altar for.

I don't go around - I don't do a lot of things I could go through as far as $\sin$ is concerned. I fall short as far as having patience sometimes. One of the things ministers feel guilty of if they're not careful or conscious of, the fact that we are trying to minister to other people all the time. AlI the time, whether I'm at work, or at home. What happens is that when I do get home, when I try to unwind sometimes, my daughter comes to me - I'm liable to bite her head off. You try to let yourself all down all at once and all of a sudden you're interrupted. What I'm saying is that these are not necessarlly sins, per se, but they're imperfections. Let's face it, everyone has them.

There are also besetting sins, sins that no one but you and god knows. I know there are things such as things I used to do that I don't do any more. I'd have to also admit that I can't honestly say before God that I don't think about some of these things. I don't dwell on these. And when I do think about some of these things and when they come back into my memory - because I'm seven years old in the Lord and thirty years old in world - and so I have all those years that I remember a lot of things and I wish to God that I didn't remember. And again, these are the things there that we hit the altar for many times that we might have the mastery over, something l1ke the proverblal thorn in the flesh that Paul had. If you ever had a sliver, nobody ever sees the sliver but the sliver realiy hurts. Altar calls - It is something you should ask for...

The Informant, here, hints at the 1dea that there exist numerous needs for which one could "hit the altar," or in other words, there are different reasons for hitting the altar. These reasons are instructive for they illustrate the meaning of hitting the altar. For instance, 
A Brother has really hurt me, stabbed me in the back, so to say, spiritualiy. And if it is really causing pain I have to go to the altar. Because if $I$ don't, the pain leads to bitterness which could lead to hate. You can't be an instrument of love and an instrument of hate at the same time. So that's one example why you would go to the altar.

A second example given by my informant revolved around his feelings as a minister. As a minister, he is never satisfied with the amount of time that he studies, to the point where he almost condemns himself for not doing enough.

Why can't I stay up all night one night a week, why can't I do this and why can't I do that. That's where wisdom comes in. The Book of Proverbs talks about wisdom. That's why so many times I have to say I'd like to, God knows that I'd like to but I have to hit the altar because I want God to speak to me. I want God to speak to me, either yes I am right by feeling that way because sometimes maybe I have slacked off a little bit. Maybe I haven't done as much as I ought to. I'm not saying I'm up on the mountain top all the time; I try to be. Sometimes I'll go up to the altar and God says, "Yes, you haven't been doing enough." But I want God to tell me that. And when God telis me that it doesn't feel good. It hurts, because I realize that God never lies and if God tells me that then I have failed. But you don't find things out like that just sitting down and just thinking about yourself. At least I can't. I try to do that but God knows how I really do things. That's one of the reasons why I hit the altar.

A third reason for hitting the altar involved a wish to discover what is bothering people. The informant acknowledged that people today are burdened with all kinds of problems and are afraid to confide in other people 
about such problems. So, one of the reasons he goes to the altar is to pray that God may reveal, transfer one's needs "directly from their heart into his heart."

This is the sort of thing that has to be part of the church because most people are always holding in. That's one reason why I go to the altar, because I really want to know what is bothering people. I don't want to know in a sense of being nosey, but the Bible is very clear that we are to pray several ways: we are to pray with the knowledge and we are to pray in the spirit. Paul said, "I praise God that I speak in tongues more than you all." What he's saying is that I pray with the understanding and I also pray in the spirit.

Another reason the informant hit the altar entalled a personal need to change the feeling of obligation he had toward his wife into a love for his wife.

I felt that God wanted me to go through with this divorce and separate and God would provide for them. I was going to go out and serve God to my last days, and that's what I felt because I did not feel love for my wife, I felt an obligation. I don't want to live the rest of my life Just being obligated to someone. I prayed to God, I said, "God, if you want me to go back there you have to give me love for her that I never had. "God heard my prayer and $\mathrm{He}$ gave me love for my wife that I never had.

A final purpose stated by my informant consisted of

a need to keep alive

...the love for those that even hate God. I found that if I could love them in a way the same thing that Christ sald "forgive them for they know not what they do." They don't know what they're doing. They don't know what they do when they say J. C. this and that, and taking the name of the Lord in vain and doing all kinds 
of abominable things. But God has given me the ability through His revelation that it is possible to love even the ungodly... And so, again I don't ever want to lose that. I hit the altar many, many times. I want God to keep it alive, to keep it vibrant, to keep it right.

These examples do Indeed demonstrate different reasons for hitting the altar, whether it's to prevent hatred of someone, to have God speak to you, to discover what is troubling someone, to ask for love (which you never had) for someone, or to keep a love you have for someone vibrant and alive. These reasons do differ from one another, yet they all have one thing in common - they all involve a perceived need to change something. For instance, in the first example, there is the need to change pain, which could lead to hate. In the fourth example there 1 s the need to change the feeling of obligation to something more - love. This notion of equating "hitting the altar" with the need to change something was nicely stated by my informant:

In my mind I equate the altar with - a-l-t-a-r with a-l-t-e-r. Whenever I want to change something in my life, I go to the altar.

Given the bellef that no person is perfect and is always in need to change something in his/her life, one might think that the only event occurring at worship services would be people hitting the altar. Such is not the case, at least, not at the Highway Church of God. 
I don't have the altar call the way many Pentecostal preachers have. In probably most Pentecostal churches, it's not a service until everybody gets up to the altar and prays. I don't consider myself to be a rebel but I do look at one thing - If this is the time to go up to the altar, how much real prayer are you golng to get? I want people to come to the altar. Nothing makes me feel better as a minister, nothing then when I minister God's Word and I see someone move on 1t. I can preach 20 or 30 dynamic sermons or what have you and it won't mean nothing. If I preach one Scripture and touch someone to the point where they break down and seek God because of that Scripture - this 1 s why I try to tell them be led by the Spirit. When you feel, no matter what time of the service; when you feel the need to pray, to seek God, something God has told you, and if you're like me, or like anybody else, many times God has told me something and I've sald, "that's good, I"ll act on 1t later on." So even in worship service when the umption comes, you feel you"ve got to do something about 1t, you've got to do It and that's when you go up to the altar.

When I say go to the altar, I don't necessary mean even then come to the front of the church. That can be the case depending on how deeply the Lord deals with you on a particular subject matter. To me, the altar is whenever I see someone really getting touched by the Lord. That's why a lot of times after I preach I have everybody stand up and to me, they're at the altar right there in their pews. I don't want to call them down like many people do and they're going to come down and they're gonna say, well, I don't want the pastor to be disappointed in me, so I'll go down to the altar. And many people do that. I don't want people serving me, I don't want people making me happy. Nothing w1.l make me happier than if, as I sald, If I preach 20 weeks of prayer, that person comes down and asks me after the service is over, even after everybody is gone, please pray for me. Sometimes people are not as outward as other people, and after everybody is gone, the message is pray with me, I need help w1th something. To me that's a true altar call. We have altar calls but I don't have them every service, per se. 
The idea of nonroutine worship surfaces again. Altar calls (or the event of hitting the altar) do not occur at every worship service at the local church. When they do occur it is not because they are part of a formula which designates what is to take place at a worship service. On the contrary, they occur when someone "is really touched by the Lord." Further, when they occur they are not routinized, rather the altar call is subject to individual preference.

This perception fibes with my own observations. During my several visits to the Highway Church's Sunday services, I observed the non-ritualistic manner in which altar calls occurred. First, I did not observe an altar call at every worship service and second, of those I did observe, none occurred in the same manner. In one instance, a member went forward to the altar and stated that "while he was praying the Lord had told him to go forward and pray for the Pastor and his family." At this time, the Pastor and his family joined the church member and the minister working under the Pastor at the altar, and prayed. In another instance, while the assistant minister was talking, a member got up from his pew and went and knelt at the altar. The minister stopped what he was saying and asked the congregation to bow their heads in prayer. During this time the assistant minister put his hand on the member's shoulder and prayed aloud, as did other members of the congregation. The church member at the altar began crying, 
letting out loud cries at times. When the minister working under the Pastor finished praying, the member returned to his seat still sobbing. The minister went on to explain that, "We - anyone, should feel free to come to the altar at any time during a service when the spirit leads them and not to feel ashamed."

Finally, in yet another instance I observed, a female member got up to give a testimony. Despite several attempts to continue, she couldn't, due to the fact that she was crying. At this point, the minister working under the Pastor said he "felt a need for prayer and that we should all gather around the altar and pray for each other and each other's needs." Everyone approached the altar and knelt down. The Pastor started at one end of the railing and his assistant at the other end, and each put their hands on the members' heads or shoulders and sald a prayer out loud for each of them. This continued until both had prayed for every member. Concurrently, the other members at the altar were also praying aloud. The members returned to their seats when they were ready. The entire episode produced a staggering effect.

These observations illustrate the non-ritualistic pattern of the event of hitting the altar, expressing again the notion that the events should come about as the result of the leading of the Spirit (see the second instance discussed above) and not because it's an expected ritual. 
I don't want people to do anything because it's a ritual or it's a form. I want people to feel free to just gather around the altar and hold hands with another and just close our eyes and just pray for each and everyone there. Sometimes, as a spiritual leader, I ask for that to happen mainly so that a habit might be able to be formed. Not the habit, per se, of getting together, holding hands and praying, but a habit - of eliminating possibly the fear of dolng 1t. So if you, because of a certain loose form are led to pray several times, then when the spirit really moves upon you to do it, then you will be less afraid to do 1t because you'll have had the proper spiritual training to do it.

God wants people that come to Him with their hearts, not Just with an outward physical show.

Hitting the altar illustrates quite clearly the conceptual scheme of the local congregation's nature of religious commitment. Members are to hit the altar "with their hearts" and not just as "an outward physical show." The event of hitting the altar should be the result of the leading of the Splrit. The important aspect of the event is not the outward physical manifestation of the incident, which is observable by any person in attendance at a service, but that the incident occurs as the result of the leading of the Spirit. In other words, a need of a person to change something in his/her life is such that they are led by the Spirit to hit the altar so that God may help them to bring about that change, to a-l-t-e-r that something in their lives. Overall, the importance of the event lies in its spiritual dimension and not in its physical form. 


\section{Hitting the Floor (Being Slain in the Spirit)}

First, in exploring the event of "hitting the floor," let's begin by looking at a native account of what takes place during this incident.

Well, you have to be careful in answering that because it's not necessarily the same thing every time. I can only speak from my own experiences. I have been what they call "slain in the Spirit" several times in my Christian experience. And sometimes the situations are similar. But then each time it seems to be yet possibly somewhat different, also. Sometimes there's almost like a semi-conscious state. You sort of hear the people and you sense the people but you're really oblivious to that. You're there but you're not there type of thing. And there are other times where you're completely out of it; you don't even know anybody else is around, whereas, other times you can distinctly make out volces, people talking, singing, or whatever the case may be going on about you.

These bodily conditions of "semi-consciousness" and "completely out of it" were explained by the informant to be the result of having reached a "spiritual level" where one is "bvertaken by the power of God." When someone reaches such a level, they have reached "that spiritual point where they feel this oneness with their creator..." The most telling feature in the above description is that the event is a state in which one is "overtaken by the power of God," producing the feeling of "oneness with their Creator." Th1s awareness of the "power of God" is the common thread which unites every instance of "being slain in the Spirit." What may differ in each eplsode are the bodily conditions experienced by the person hitting the 
floor. The person may feel they are in a "semi-conscious" condition, they may feel "completely out oi it," or their whole body may feel "very weak, very wishy-washy...I1ke a million needles all over their body." Other times,

I've had the power of the Lord come on me several times where I just couldn't stand on my feet, literally (I) fall down to the floor. That's what we call in the church "being slain in the Spirit."

Whatever the physical condition felt by the person hitting the floor, such behavior according to my informant ought to be the result of a sincere search for "total involvement with the Lord." In a discussion of different reasons for hitting the floor, however, this state of affairs was not found always to be the case:

There are different reasons. There are some good reasons and there are some bad reasons. For every genuine spiritual encounter and truthful thing that exists in the realm of God, there are also counterfelts. There are also things that are very close to - and people are very good actors. It doesn't take very long for a person to know how to act a role out. Some people, agaln, talking about these kind of people - what happens sometimes, a person who may be stepping away from the Lord, in some way or another, they might try to cover up that with a superspirituality type of thing. Just like a person was very shy, quite oftentimes is someone who is very bolsterous. It's a coverup, a mask. I would say that would be a rare case. But again it depends on the church you're in. You might find yourself in a church where most of the people are phony, in plain English. They just get wrapped up in the fact that "we're superspirttual people" here. Some people are just that, they've bulit around the emotional end of the worship. Again, someone goes up there and kneels down and gets slain - "Well, hey, I'm not golng to let him outdo me." These are not nice things to say but they're human nature, things that really happen. 
The idea that people can physically imitate the event of hitting the floor without actually being "overtaken by the power of God," without experiencing the spiritual aspect of the event, was expanded by my informant:

... Whenever there is something real about God, there will also always be a counterfeit, because there is the power of God and there is the power of Satan. And what better way to keep someone from really reaching the true power by putting a pretty close proximity to it, right next to it. That's what happens a lot, in seeking the things of the Lord is you can get very easily led astray from the real thing. There are churches you can go into, and there are people who are slain and fall prostrate on the floor, then I wouldn't dare say these are all by the power of the Lord. You see, if someone is trying in their conscious or subconscious mind - trying to equate that they're better than they really are, what better way to do it than to show that God has really blessed them.

In other words, you have:

People wanting to make themselves out to be spiritual in a carnal way. Like many other things, there's elther the truth or falsehood. You're elther sincerely seeking something and recelve it or you want other people to think you're seeking something.

Aslde from these negative reasons for hitting the floor, which involve physically acting out the event in order to appear spiritual, there are good or positive reasons for being slain in the Spirit. A positive reason involves emotional problems: 
people---. One of the ways you could put it would be this - if you had a highly traumatic experience you'd just gone through or a nerveshattering experience that you just didn't know how to cope with - many times one way you can find relief is again, taking this burden that you have directly to the Lord... And when you get into that habit of praying, and intercession for others, then you can actually find yourself in a state where you seek this total involvement with the Lord, which would be possibly being slain in the Spirit.

Another good reason involves physical problems:

In some cases it's a physical thing. I've had times when I've needed to be touched in my body for healing, and I've had times when I've gone before the Lord and prayed and reached that level and allowed myself to reach that stage, and then after, again after the fact, I'd realize that, hey, I don't hurt anymore, why? How did 1t happen? I don't know exactly how or why but I know that when I really feel that I've prayed, and really reached the Lord about something, then something is bound to happen. And generally speaking, to me, that's really a clear-cut sign whether you have reached the Lord. If you pray to the point where the power of God just comes upon you - you're just overwhelmed, you're overpowered then I think everyone should pray to that level.

In summary, then, the event of hitting the floor is an incldent in which one is "overtaken by the power of God," an eplsode in which one has sincerely sought total involvement with the Lord and reached 1t. The person who experiences being slain in the Spirit senses a "genuine spiritual encounter" with God. The person who physically 1mitates the experience without ever actually feeling a "oneness with the creator" succeeds in only 
deceiving other people into thinking he/she has received this feeling. The local congregation's conceptual scheme of the physical and spiritual dimensions of their religious commitment is acted out in regard to this experience of hitting the floor. People should genuinely or spiritually seek total involvement with God. Again, it should come from the heart and not only as an outward expression or form they have to imitate for the sake of appearing spiritual. How does one tell if the event is the result of a genuine spiritual encounter with God and is not counterfeit? According to my informant, this is a gift of the spirit "discerning, the discerning of the spirit, to know whether something is of God or not," - a topic beyond the scope of the present investigation.

\section{Giving Testimony}

The event of "giving testimony" is considered an important aspect of worship service at the Highway Church. The importance of the event lies in what takes place when someone gives a testimony. When someone offers a testimony, two things are happening. First,
Number one, the Bible tells us that we are to declare that there are many works of God in the midst of the congregation. In other words, scriptually, we are exhorted to do that, in the Bible. To let the people know what God has done for you.

This idea of sharing with other members what God has done is demonstrated in the following example: 
For instance, I shared with you last time how I had been praying about a week ago, "Lord, let Brother White call." He's a Christian brother I haven't seen in several months and I was really burdened (about) him. I was on the way home from some place that night. I was praying this to myself and five minutes after I go in the door here, a phone call came from Arizona, or Oklahoma where he lives. There was an answer where I'd prayed and the Lord knew that I was troubled about this particular situation. I don't believe in coincidence. And when you pray something specific like that and it happens - when something like that happens and you verbalize it in church, someone maybe who has not set their fatth loose ever before would be encouraged to do that. Some people think that certain things are too big to get to God, some people think things are so trivial they don't want to bother God with (them). And when people stand up and testify, every testimony is not something big - colossal, supernatural, gigantic thing that God has done.

The following testimonies given by two members of the Highway Church exemplify the notion that not every testimony has to be something of a grand nature:

I would just like to thank the Lord for a beautiful day.

Last Thursday I was coming home from work and my car was running on $E$ and $I$ don't mean a little above $E$. I mean directly on $E$ and $I$ prayed to the Lord, I said, "Lord, let me get to the bank and into the gas station." And I traveled in that car, I know, on faith. But I got to the bank and I got to the filling station and it's not anything that I could do but 1 t was the Lord.

Because I know if I had depended on myself it probably would have quit on me before I got half-way. But I pralse the Lord for $1 t$ and we can depend on Him for our very needs. It sounds like something small but it might be small in our eyes and to someone else but to God 1t's an Important thing and He takes care of our Individual little needs. And we need to rely upon Him for everything... 
As noted, not every testimony has to be of a grand nature, but some of them are. The simplicity of the "beautiful day" motif stands in sharp contrast to the following example:

Sometimes - I had a call today, my wife talked to the daughter of the fellow I went up to see at Norwich. She was driving along In the car just a couple of days ago and this car quite a distance away was coming towards her at an extremely high rate of speed and it looked like she actually was going to be run over by this car. Evidently the fellow had fallen asleep behind the wheel, his foot went down on the accelerator; he was going like crazy. She couldn't go to the right; there were cars in front of her; she couldn't go either way; no place to go. The only thing she could do was call unto the Lord, "Lord help me." Instantaneously, at that moment - the car was only feet away from her - the man in the car came to his senses, slammed on the brakes, went off the road and crashed. In other words, there's a testimony, there's where her life was actually saved because of that!

Var1ous members of the congregation take the opportunity to share testimony, to declare to the other members present what God has done for them because:

It encourages other people to maybe try the Lord in that aspect. It bullds up their falth, to give the Lord a try. In the Word it says, "Try me." God actually says, "Try me, if you don't believe in me, if you don't know me for sure, try me to see if I will be falthful to you in your need." So that's really what we do.

The second Important aspect of testimonies is that they "reaffirm that God is alive" and they "glorify" HIm: 
But testimonies are important to reaffirm that God is alive. The churches that don't have testimony service, I'm sorry to say, I won't say they're all dead churches - but many of them are. They don't believe in the existence of the living all powerful God. And because they don't belleve in that they don't get what they don't believe.

It's a matter of glorifying the Gospel to one another.

The following testimonles from members illustrate the glory given to God for things He has done. Again, the episodes related run the gamut from simple to grand.

...I'd just like to praise the Lord and tell Him I love Him.

I'd like to praise the Lord; stand up and thank Him for saving me. Thank Him that those shackles of bondage have come off. I'm grateful to the Lord for being able to stand here in this wonderful, beautiful house of His, with beautiful Brothers and Sisters, It's just overwhelming. Thank God! You know lately it just seems like when I first have a need and I really start to begin to pray for the need that I have, the Lord supplies that. He glves me what I need. He gives me the answers that I"m seeking for and I would just stand in His house and just tell HIm that I love Him and I do. I recognize my heavenly Father and I praise Him and I thank HIm and I thark HIm for all the beautiful and wonderful Christian fathers and men. And praise God, they're just as important as the mothers and the wives. Pralse God for these men of God that take this responsibility and they take hold of it and they ask God for guldance. I thank God for my husband, for the father that he is to my daughter and I Just praise God for that.

Thus far, we have seen that two things occur when a testimony is given: gloriflcation of God and declaration of what God has done for someone. In other words, when a 
testimony is given, it is given

...number one, to glorify God, and we do it, number two, to declare to the congregation the handiworks of the Lord to encourage them to also trust the Lord in that particular aspect.

These two aspects of a testimony are further illustrated in various types of testimonies. For instance, there are healing testimonies. During a service I attended one member rose to testify, thanking the Lord that she was able to be there for she wasn't feeling well saturday night. My informant also admitted to sharing healing testimony: "I have been healed several times by the power of the Lord, not by - regular, ordinary medical means. I have given testimony to that, that God might receive the glory from it." In addition to healing testimonies, there are financial testimonies. My informant related such a testimony about a time when he was hurting financially. His wife had quit work and ends were hard to meet on only one 1ncome. On his way home from work one day, he paid some b1lls and ended up with only ten doliars with which to purchase the week's groceries. When he got home and changed into his work clothes, he discovered in his pants' pocket what he thought to be "some sort of old ripped up notes." It was, however,

...e1ther thirty or forty dollars that was in my pocket. Now I know I didn't put it in there. And I know the Lord did. You might find 1 t hard to comprehend, but I know it wasn't mine. I don't mislay forty dollars. I might just mislay fifty cents, maybe even a dollar or two, but you know when $1 t$ happened I just knew it was the Lord 
that did 1t. Put forty dollars into my pocket. So instead of going on with just ten dollars, I had now forty or fifty dollars.

And then someone walked up to me the following day, shook my hand, and gave me twenty dollars. Now I hadn't said anything - not that I'm too proud, but I don't go around crying when I'm hurting, because I expect to hurt sometimes. So the Lora provided my financial needs for that week there. He provided sixty dollars right out of the clear blue. Twenty dollars just through a person who was led to do that. Now that was testimony and again, I needed to share that because some people might say, I just can't do 1t, I haven't got nothing, my just letting go with this would cause someone to say, I don't care, God is my God, and I love Him.

Further, there are emotional testimonies.

There are mental - I have been emotionally and mentally healed by the Lord a couple of times. I don't drop off the deep end. But there are times that you come across certain things in your life where it can be very traumatic experience or upset you quite deeply. In a mental state where you're healing or your physical state begins to get in a state of neglect and a depression might even set in because of certain things that happen. One that comes to my mind is the death of a love one. A truly traumatic thing. Having coped with something like that several times and I've had really problem times mentally and the only way I could cope with it was to just give it to the Lord. Pray. I can't handle it myself and you'll have to - the Bible says "...cast all the cares upon me for I care for you." I had to cast them upon HIm because I was incapable of coping with them. And the Lord just delivered me, I could feel the weight lifting off, and just being relleved.

Finally, there are testimonies of deliverance. Again, during my attendance at a Sunday worship service, a member stood and gave a testimony about being able to give up 
coffee, something she had been wanting to do for a long time. She wanted to thank the Lord for giving her the strength to do it. She'd been wanting to do it but didn't know how she was going to be able to, but with the Lord's help she did.

Overall, the varieties of testimonies illustrate different events for which members feel the urge for declaration or glorification. The physical dimension of this event is located in two areas: first, in whatever it was the Lord did - the outward show, whether it be the healing of a sickness or thirty dollars in an empty pocket; and second, in the verbal expression of the occurrence to the congregation so as to encourage others to also trust the Lord. The spiritual aspect of giving testimony is that event being testified to came about as the result of the Lord. The event occurred because of the trust - the one more felt than seen - which that person had in God. In sum, the local Pentecostal group's conceptual strategy of the nature of their religlous commitment is also acted out In the event of giving testimony.

\section{Conf1rmation from God}

"Confirmation from God" is an event which involves a way of living, a "spiritual way of living," according to one member of the Highway Church. This statement of the significance of conflrmation from God is further explained in a discussion with the principal informant of this study: 
The Bible says that we are to prove all things. Confirmation. A preacher says something, you receive what he says, you think about 1t, and you accept it or reject it. The Bible says that you're not supposed to accept it unless it is confirmed by the Word of God.

Wy informant went on, once again, to cite Scripture to prove his point.

The Bible says that when Paul went about setting up churches through Asia, he saw that the people in Berea were better in one manner than the people that were at Thessalonica. Why? Because they searched the Scriptures out. When Paul told him this, - this spiritual truth, that spiritual truth, they said, in essence - "Show me in the word of cod where it says this." "Show me" - they didn't have the New Testament but they had the old Testament, the flve books of Moses. They said "show us," let us reason together, it says in God's Word. Confirmation ultimately, has got to come from God, is what I'm saying.

This notion that confirmation must ultimately come from the Word of God was expanded upon by my informant. My informant discussed people who are known to be very knowledgeable about the Bible. He noted, however, one should st1ll not take their word for anything. "You check 1 t out and you confirm it against the actual written word." He went on to point out how some people preach that once one becomes a Christian, "everything is going to be easy for the rest of his/her life." The informant states, however, that

The Word never says that, but some people preach that way, and that's why you've got to be very careful and study and read and check it out and confirm it with the actual written Word of God. I belleve the Blble to be, 
as we have it, the infallible word of God... Times change, people change, everything changes, and the Bible says, even heaven and earth will change, there's going to be a new heaven, a new earth. But the word that we have right now, we call the Bible, is golng to stay the same. So again confirmation - for confirmation one must always go back to the Bible.

Thus, the description of the event of confirmation from God as a "spiritual way of living" involves the idea that before accepting something which someone states, or before acting on a thought or impuise, one should confirm it with the Wcrd of God. If something is truly of the Spirit - whether it be a thought or an impulse to act on something in a certain manner - it will be proved to be so ultimately and infallibly by the word of God. In fact, my informant cited several Scriptural examples in which confirmation from God is illustrated. One particular example he mentioned involved Gideon. God wanted Gideon to lead his small army out to do battle, agalnst a "mighty army." Gideon wasn't sure, however, that this was really what the Lord wanted. So, he tried the Lord. Gideon put a fleece outside his tent and said,

"Lord, if this is You speaking, I want this to happen, this skin that I've put out is going to be totally dry, even though everything else is sopping wet." And it happened. And it was God's Word conflrming to His man that this was indeed something that He wanted $\mathrm{hIm}$ to do. And GIdeon said, "Well, I don't know, better try two out of three" - type of thing. Instead of having fust the fleece dried now he wanted fust the fleece to be wet. And again, it happened, exactly as he said it before the Lord, The Lord wanted to confirm 
that He was indeed behind them.

... when God really wants you to do something

He reaffirms it.

This sample, once again, illustrates my informant's

ability to cite Scripture which demonstrates his point.

In this case my informant also conveyed personal

experiences in which God reaffirmed and/or confirmed a

situation. One experience involved Easter. My informant

had several services to conduct and was seeking the Lord

for these services. He had one particular thought which

he could not shake from his mind, "the sunrise service."

The sun coming up over the water, and ther

when I thought about the sun, the s-u-n

coming up over the water, I thought also,

again as the S-o-n of God coming up out of

the tomb, and then I was trying to think

how - you know - what about this thought.

After several days of studying, my informant still "hadn't penned anything down for any of the four services." Then, his wife gave him a placemat.

...it was this beautiful placemat with a picture of the sun coming up over the water with Psalm 113, verse 3 . It says, "From the rising of the sun to the going down of the same the name of the Lord is to be pra1sed." Soon as I saw that thing I knew it was confirmation, God was confirming that $I$ was to talk and to speak about the rising sun, but I don't Just get up to speak for the sake of speaking; it's got to be backed up by the Word of God. And there she walks in w1th the Word of God that says exactly what's been on my mind for the last three or four days. Confirmation, that's what God wanted me to preach on. 
...now my wife she got that poster six months ago, but she didn't give it to me until Friday. Now, she didn't know why but you know, God confirms - when the confirmation comes, I tell you, you - it doesn't happen all the time but when it does, what an elation - to know that God is really saying, in other words, "Yes, that is what I want you to talk about." Sometimes, admittedly, you go back there and you do your best, you do what you feel God wants but you don't have that confirmation. But I don't expect a confirmation but when 1t does come, it lets you know what God's volce sounds like.

The understanding that confirmation from God doesn't occur all the time is illustrated in the following discussion.

I was going to a funeral and I went to the funeral parlor and was looking at the deceased person. I didn't know him personally but through friends and through his brother, and I said, you know, I believe in the Word of God and the Word of God says that the dead shall rise, that we have the power. And I thought to myself, I said, I could go up there and I could lay my hands on that person and he'd rise from the dead. I have that power. Then it was like the Lord was saying, "Yes, you have that power if I give it to you."

...I put a fleece out to the Lord. I said, "Lord, if you want me to do this, I won't be ashamed of you, I'll do it, I'll go right up there," and I put a fleece out to the Lord and the Lord didn't answer the fleece, so I knew that it was not Him that was asking. In other words, I wanted to do it because I believed in God. This is, again, the important thing with the things of the Lord. The word of God is true and His spirit and every (thing) - but God has got to actually confirm that word to you in order for it to be something you can walk out on, sort of stick your neck out on.

The fleece the informant had put out to the Lord - 
I sald to the Lord my thought, I said this specific I can share with you: There were on lights in the funeral parlor, all around, and two lights around the coffin. I said this to myself, "Lord, if you want me to do this, I said, I will do it, but I want all the lights to go off and just the lights where the coffin is to stay on." That was my fleece to the Lord. Now if that happened I probably would have dropped dead. But the thing is, I like to belleve that I love the Lord and I trust the Lord enough that, if that had happened I would by faith have done it, because that was my confirming sign from God...

The Bible says "Try the Spirits." Try the Splrits to see whether they are God. And that's why again, I made this fleece. Only God, by knowing my heart and knowing my mind, only God would know the sign I was looking for. And so therefore I tried the Spirits. It didn't come to pass, therefore, it couldn't have been God because God could have done anything.

This incident illustrates those episodes where confirmation from God is not received. The informant did not recelve the knowledge from the Lord that He wanted him to resurrect the deceased. Therefore, the informant knew that the Impulse to perform this act was not of God. Thus, 1t was not executed.

Next, although confirmation from God ultimately comes from the Word of God, the Word of God may emerge from different sources. This aspect is explained in more detall by the informant:

There are times when a certain subject will come up, let's say a touchy subject. A touchy subject today, in this new permissive, promiscuous society that we're in - is sexuality. If you're led to preach on a particular aspect or a thing about, I don't know of any minister that would shy away from 1t. In other words, 
it's a very touchy thing to preach on but at the same time if and when confirmation comes, the Lord will sometimes, again, give you through maybe two or three different people, Brothers and Sisters, during the course of a week, as you're praying before God about this because you feel a burden on your heart about the subject as related to what we were just saying. And then this sister will come out with a scripture that has that as part of the contents in 1t. You'd be listening to TV or something or other and maybe "That's Incredible" will be on - something that's not spiritual, and Bam, another Scripture. Come to think of 1t, Isn't it exactly what I was saying. The Word of God - confirming, and that's one of the most likely ways that confirmation does come from different sources but still it's the Word of God that does the confirmation about really what the burden is and that makes sense, because the Spirit of God, which is God, is what inspired men to write the Word. If the Spirit is true, God is true. In Him is no lie, He is incapable of lying. So if I really have a burden about something, then that spirit of truth that abides within me will reaffirm that, that is what I'm supposed to be preaching on. It will also confirm that by other means.

The notion of confirmation emanating from a variety of

sources is further illustrated in the following example:

Last Monday night, the night of the seminar, I'd read the whole book, the whole teacher's thing on the ministration of the Holy Spirit and I enjoyed the whole thing, it was very beautiful. It was hard for me to decide what I wanted to teach on, and I chose the last chapter. It was the Holy Spirit - the equiper - He equips us with the proper tools to do the job, and I called the District Overseer and I sald I didn't know what, maybe, he chose that one because two of us were going to be teaching simultaneously. I sort of felt in my heart, well, probably that's the one that he wants, and I sald, well I'll choose something else. So I called him up and he sald, "That's O.K." I said, "Praise God!" 
Despite this confirmation from the District Overseer, my Informant still had doubts that the Lord really wanted him to teach on the chapter he had chosen. These doubts did not linger long.

...I came home Monday and there was a letter in the mailbox from the head of the church of God, the General Overseer. All that comes to mind from that whole letter is that last sentence. He was talking about the Holy Spirit equipping the saints to do an effective job, and when I read that I got so - It was confirmation.

Further, my informant c1ted yet another source of confirmation which pertalned to this episode.

The results of last Monday, I believe, was confirmation because I'd feel in my spirit that several of the people that were in there - I know that the Lerd moved. I was teaching and people were crying. The Lord was just moving and minlstering in what I was bringing out. Not that is was me. It was just the power of God. God was using me at that particular time to bring forth that particular message. And so that in itself, after the fact, was additional conflrmation. First 1t was the Brother, then the letter, then the actual - ...

In sum, the local Pentecostal congregation's conceptual scheme of the nature of thelr religious commitment is also manifest in the event of confirmation from God. Confirmation from God is the manner in which something is proven to be of the Spirit, to be of God. Again, the confirmation may take the physical form of a poster with a Scripture on 1t, a letter from a church 
member, a testimony given by a Brother or Sister, or an actual "fleece" put out to the Lord. But more importantly, confirmation from God evidences that something is of the Spirit; it is God's way of revealing what He wants from someone. Instead of acting on impulse, the members walt to be led and gulded by the spirit thus, as a result, their actions are the product of the direction given by the Spirit for they are conflrmed by the Infallible Word of God.

\section{Conclusion}

Overall, the ethnosemantic description presented in this chapter demonstrates that the view which the members of the Highway Church of God have of the nature of their religious commitment differs substantially from the conceptual scheme of religious commitment as proposed by social sclence researchers. Although the social science scheme was applicable when examining the descriptive histories of the Pentecostal movement in general and the Church of God of Cleveland, Tennessee in particular, the strategy was not applicable when investigating the data gathered on the insiders' (members') viewpoint at the Highway Church of God. Rather than being able to sort the information gathered Into the dimensions of belief, practice, knowledge, experlence, and consequences, the conceptual framework of the nature of religlous commitment which repeatedly surfaced in the data concerning the Iocal group consisted of only two dimensions - the physical and the spiritual. 
The physical and spiritual dimensions of religious commitment were 1llustrated in several discussions which covered various topics, including worship, God and religion, what is involved for someone who lives Pentecost, the acting out of different types of worship services, the nonroutine occurrence of events at church services, and the knowledge which pertalned to these various topics. Further, the congregation's conceptual strategy was shown to be acted out in four specific events occurring at the Highway Church: hitting the altar, hitting the floor or being slain in the spirit, giving testimony, and confirmation from God. These events consisted of both physical and spiritual aspects.

The importance of the splritual aspect over that of the physical in the Highway Church's nature of commitment was also demonstrated in the data concerning the group. The private level showed the domination in a discussion concerning "living Pentecost." The public domain, which included the acting out of different types of worship services and the nonroutine occurrence of events at services, also evidenced the perception of Pentecostalism as something more felt than seen. Further, in addition to these general levels, the Importance of the spiritual aspect was acted out in four specific events. The significance of these phenomena, at whatever level, is that they occur according to the "will of the spirit." The true meaning of religion for the Highway Church of God does not exist in any physical 
form. The important element is that the members seek the Lord in a spiritual sense, a sense more felt than observed. The physical dimension of the Highway Church's conceptual framework of the nature of religious commitment is clearly overshadowed by the spiritual dimension.

The next step in this project is to investigate the implications of these findings. Suchatask entalls exploring what reasons may explain the Inapplicability of Stark and Glock's (1968) conceptual scheme of the nature of religious commitment to the insiders' view of the same phenomenon. Further, an effort will be made to indicate Just what effects or consequences the Highway Church and its religious commitment has for its members. 
CHAPTER IV

OUTSIDERS AND INSIDERS:

SOME CONCLUSIONS

The Stark and Glock (1968) scheme of the nature of religious commitment proved to be applicable when researchIng the descriptive histories of the Pentecostal movement in general and of the Church of God of Cleveland, Tennessee in particular. When lookirs at the descriptive histories of these two religious movements, one is investigating material which represents the empirically observable expression of events or behaviors which have occurred throughout the movements. These public events and public behaviors fell neatly into the dimensions of the conceptual strategy of the nature of religious commitment suggested by the social science researchers. In other words, the sociological scheme was useful in the investigation of the priblic faces of religiosity of the Pentecostal movement and the Church of God.

The utilization of the sociological scheme of the nature of religious conmitment, however, was not applicable to the investigation of the data expressing the manner in which the members (or Insiders) of the Highway Church of God viewed the nature of their religious commitment. The native viewpoint manjested its own structure (physical spiritual) rather tran the five-dimensional format proposed by Stark ard GIock. This inside viewpoint was 
captured principally by preserving the language the members of the congregation used in talking about their religion. In this instance, the native language of the local Pentecostal group provided the cultural knowledge used by this culture's members to define and interpret the nature of their religious commitment. That interpretation differed from the sociological scheme proposed by Stark and Glock. The conceptual scheme of the nature of religious commitment suggested by Stark and Glock, therefore, could not be appropriately utilized when describing the private face of religiosity. The private face, the insiders' viewpoint (a viewpoint which exists not only within individuals, but also within congregations) requires description in its own terms If it is to be preserved.

Thus, in evaluating the utility of the sociological scheme of the nature of religious commitment, it appears that the applicability of such a conceptual scheme is limited to the public face of religiosity. When examining only the behaviors exhibited throughout the Pentecostal movement and the Church of God of Cleveland, Tennessee denomination, the employment of the sociological scheme proved successful. The behaviors which occurred throughout the religlous movements were able to be placed in one of the five identified dimensions of religiosity. When the investigation of the nature of religiosity switched from the public face of the phenomenon to the private face, however, the sociological scheme of the nature of religious 
commitment was no longer applicable. Once the inquiry went beyond only behaviors to examine the cultural knowledge (the meanings and interpretations) associated with the behaviors of members of the Highway Church of God, the conceptual scheme suggested by Stark and Glock was not useful. The members of the Highway Church viewed the nature of their religious commitment differently than the definition advanced by the sociological scheme of religiosity. Instead of viewing the nature of their commitment along such dimensions as bellef, practice, knowledge, experlence, and consequences, the congregation's conceptual scheme of the nature of their commitment entailed only two dimensions the physical and the spiritual. The knowledge used to interpret the various aspects or behaviors included in the members' worship was organized along physical and spiritual dimensions. The dimensions were regarded as constituting the contents of the varied aspects and behaviors of their worship. The private face of religiosity, then, which includes the subjective meanings of the behaviors involved, did not lend itself to routine sociological analysis.

As the level of analysis moved from the more abstract, denominational level, to one approaching concrete religious groups, the utility of the scheme of the nature of religious commitment suggested by Stark and Glock declined. The sociological strategy worked when commitment was examined at an abstract level, a level which involved examining behaviors with no subjective meanings attached to them. When the level 
of analysis got closer to real religious groups and to behaviors with their subjective meanings intact, the sociological scheme of religious commitment could not be applied. The inapplicability of the sociological scheme at the concrete level when coupled with the discovery that an actual religious group possessed its own conceptual scheme of commitment served to indicate the importance of preserving the native point of view. The members of a particular religious group possess their own native scheme by which they organize their behavior, they do not organize their behavior according to an objectlvely created soclological scheme. If this notion that each congregation has 1ts own view of its religlosity, complete with meanings and interpretations particular only to that group, then perhaps "Christianity" does not exist on an abstract level but only within individual religlous groups. In other words, if each congregation is equipped with 1ts own particular cultural knowledge used to organize and give meanlng to their behavior, then 1t may be that "Christianity" exists only within each religlous group as that group chooses to define 1 .

The opportunity to discover the H1ghway Church congregation's view (the insider's or native's view) of the nature of their commitment was realized by preserving the language the members of the group used in talking about their religion. Contalned within the language of that group is the cultural knowledge utilized by the members of the 
culture to interpret their behavior, to organize and give meaning to their actions. Such a system of knowledge, because it is used routinely (everyday) by the members of a culture, without them even having to think about it, is often not even realized to exist by the individuals who utilize it.

The system of meaning used by a particular cultural group to organize and interpret their behavior is not readily perceived by an outsider to that group. Such a notion was certainly true in the current situation. Without preserving the way in which the members of the local congregation talked about their religion, 1t is doubtful that as an outsider I would have discovered the cultural knowledge utilized by the members in viewing the nature of their religious commltment, especlally given the conceptual scheme which did emerge. As one member of the congregation put 1t when he quoted I Corith1ans 2:14, "But the natural man recelveth not the things of the Spirit of God: for they are foolishness unto him: ne1ther can he know them, because they are spiritually discerned." As an outsider in the Highway Church, as one not famlliar with their system of meanlng, I could not know, first hand, the manner in which the members of the group viewed their religiosity. But I could, and did, discover their view by preserving their native language.

Aside from discovering the Highway Church's view of the nature of their religlous commitment, I was able to 
gain some insight into what effects such a commitment has for the members of this congregation. The effects of the Highway Church's conceptual scheme of the nature of their religlous commitment, the effects of the physical and spiritual aspects of their religiosity, were demonstrated in several comments made by my principal informant. First, the nature of the Highway Church congregation's commitment, "means turning away from the things that you'd normally do (as a person of the world) and even the desire, and putting everything - your mind, your eyes, your whole body into subjection to the Lord." Here, the effect of the meaning of commitment at the Highway Church is that one must deny everything which one would want or do as a person of the world. "Even the desire," must be foresworn and everything must be surrendered to the Lord - physically and spiritually.

A second effect of the Highway Church's commitment is illustrated in the following statement by the informant:
A saved person just acts it, he doesn't
just speak it, but he acts it because it comes out of him all the time. As I said before, Christianity is not a belief, per se, as much as it's a way of life, a way of existence, total involvement of oneself with his Creator. Not that we go around praying all the time but it's putting what we belleve, Into peoples' day-to-day lives.

In other words, the nature of their religious commitment becomes a mode of life, a particular manner in which they 
conduct themselves in their day-to-day living. The congregation's view of the nature of their commitment extends beyond a mental lmage of the phenomenon to become an actual way of life, a method by which to carry out their everyday activities.

Overal1, the Highway Church's nature of commitment is something not only talked about, but it 1 s a matter which is evident in the behaviors of their day-to-day lives. Everyday, everything about thelr lives is subjected to God. My informant summed up the effects of the local congregation's commitment best when he sald, "When we have a commitment, then it changes our whole nature, everything changes around and eventually comes in line with what God wants. Then, He's happy with us. Amen." 
APPENDIX

March, 1983

Dear

I am a graduate student at the University of Rhode Island and am currently working on my thesis. The topic of my thesis involves Pentecostalism and how members of this faith talk about their religion. In order to complete the research for this project, however, I need some additional information. ( $I$ understand that Pastor has contacted you in regard to this matter.)

In talking to other Pentecostals, certain items were mentioned with reference to Pentecostalism about which, I would like more information. These items appear on the enclosed questionnaire which I would like you to please complete as best you can. In fllling out the questionnaire, I realize the space provided may be limiting, however, if you could please confine your answers to this space it would greatly aid in the timely completion of the research process.

Also, I would appreciate your prompt completion of the enclosed questionnaire. A preaddressed stamped envelope is provided for your convenience in returning the completed questionnaire. Your replies will be confidential and anonymous. Please, do not sign the questionnaire.

Further, should you be interested in seeing a copy of the final report, a copy will be available to you.

Again, thank you very much for your time and cooperation.

Sincerely,

Robin Gavitt Graduate Student Department of Sociology University of Rhode Istand Kingston, RI 02881 
The following questions were asked of the members of The Highway Church of God approximately one year after the inftial research was conducted. The follow-up questionnalre served as an additional vantage point of the culture of The Highway Church of God. The questionnalre was sent to five households, four of which responded.

(1) Many Pentecostals I have talked with have used the phrase, "hit the altar," in our conversations. Could you describe to me what is happening when you hit the altar? Are there different reasons for dolng it? Maybe you could give an example.

(2) Often times I have heard Pentecostals talk of receiving "confirmation from God." Could you describe to me what confirmation from God 1nvolves? Are there different types of confirmation? Different reasons for receiving conflrmation from God? Agaln, feel free to glve an example.

(3) I have sometimes heard and read about instances where Pentecostal members are sald to "hit the floor." Could you explain to me what is happening when you hit the floor? What sorts of things are you feeling, thinking? What kinds of reasons are there for hitting the floor?

(4) As part of the Pentecostal worship services I have attended, a request for "testimony" has always been made. Could you explain to me what it is you are dolng when you give a testimony? Would you say there are different kinds of testimony? 


\section{SELECTED BIBLIOGRAPHY}

Agar, Michael $\mathrm{H}$.

1980 The Professional Stranger: An Irformal Introduction to Ethnography. New York: Academic Press, Inc.

Beals, Alan R.

1979 Culture in Process. 3rd Edition. New York: Holt, Rinehart and Winston.

Berger, Peter L. and Thomas Luckmann.

1967 The Social Construction of Reality. New York: Doubleday \& Company, Inc.

Bibby, Reglnald W. and Merlin B. Brinkerhoff.

1973 "The Circulation of the Saints: A Study of People Who Join Conservative Churches." Journal for the Scientific Study of Religion 12:273-283.

Boisen, Anton T.

1955 Religion in Crisis and Custom: A Sociological and Psychological Study. New York: Harper \& Brothers Publishers.

Chalfant, H. Paul, Robert E. Beckley, and C. Eddie Palmer.

1981 Religion in Contemporary Society. Sherman Oaks, California: Alfred Publishing Co., Inc.

Clark, Elmer T.

1937 The Small Sects in America. Nashville: Cokesbury Press.

Conn, Charles W.

1955 Like a Mighty Army. Cleveland, Tennessee: Church of God Publishing House.

Dearman, Marion.

1974 "Christ and Conformity: A Study of Pentecostal Values." Journal for the Sclentific Study of Religion 13:437-453.

Faulkner, Joseph E. and Gordon F. DeJong.

1966 "Religlosity in 5-D: An Emplrical Analysis." Social Forces 45:246-254.

Gerlach, Luther P. and Virginia H. Hine.

1968 "Five Factors Cruclal to the Growth and Spread of a Modern Religious Movement." Journal for the Scientific Study of Religion $7: 23-40$. 
Glock, Charles $Y$. and Rodney Stark.

1966 Christian Beliefs and Ant1-Semitism. New York:

Harper \& Row, Publishers.

Goffman, Erving.

1959 The Presentation of Self in Everyday Iife.

New York: Doubleday \& Company, Inc.

Gordon, David Fr.

1974 "The Jesus People: An Ident1ty Synthesis."

Urban Life and Cultures 3:159-178.

Gumperz, John J.

1969 "Communication in Multilingual Societies."

Pp. 435-449 in Stephen A. Tyler (ed.),

Cognitive Anthropology. New York: Holt, Rinehart and Winston, Inc.

Hamilton, Michael P., ed.

1975 The Charismat1c Movement. Grand Rapids:

William B. Eerdmans Publishing Company.

Harrison, Michael I.

1974 "Sources of Recruitment to Cathollc Pentecostalism." Journal for the Scientific Study of Religion 13: 49-64.

1974 "Preparation for Life in the Splrit: The Process of Initial Commitment to a Religious Movement." Urban Life and Culture 2:387-414.

Hine, Virginia H.

1969 "The Pentecostal Glossolalia: Toward a Functional Interpretation." Journal for the Scientific

Study of Religion 8:211-226.

Hof stadter, Richard.

1970 Anti-intellectualism in American Life. New York: Alfred A. Knopf.

Hollenweger, Walter J.

1972 The Pentecostals: The Charismatic Movement in the Churches. Minneapolis, Minnesota: Augsburg Publishing House.

Johnson, Benton.

1971 "Church and Sect Revisited." Journal for the Scientific Study of Religion 10:124-137. 
Jorgensen, Danny L.

1982 "The Esoteric Community: An Ethnographic Investigation of the Cultic Milieu." Urban Life 10:383407 .

K1ldahl, John P.

1972 The Psychology of Speaking in Tongues. New York: Harper \& Row, Publishers.

Lenski, Gerhard.

1961 The Religious Factor: A Sociological Study of Religion's Impact on Politics, Economics, and Family Life. Garden C1ty, New York: Doubleday \& Company, Inc.

Manning, Frank E.

1977 "The Salvation of a Drunk." American Ethologist $4: 397-412$.

Menzies, William W.

1971 Anolnted to Serve: The Story of the Assemblies of God. Springfleld, M1ssour1: Gospel Publishing House.

Nichol, John Thomas.

1966 Pentecostalism. New York: Harper \& Row, Publishers.

Niebuhr, H. Richard.

1957 The Social Sources of Denominationalism. New York:

The World Publishing Company.

O'Dea, Thomas F.

1966 The Sociology of Religion, Foundations of Modern Soclology Serles. Englewood Cliff's, New Jersey: Prentice-Hall, Inc.

Robinson, W. S.

1969 "The Logical Structure of Analytic Induction."

Pp. 196-205 in George J. McCall and J. L. Simmons

(eds.), Issues in Participant Observation; Addison-Wesley Serles in Behavioral Sclence:

Quantitative Methods. Reading, Massachusetts: Addison-Wesley Publishing Company.

Selltiz, Claire, Lawrence S. Wrightman, and Stuart W. Cook.

1976 Research Methods in Social Relations. 3rd Edition. New York: Holt, Rhinehart and Winston.

Smith, Ronald $W$. ana Frederick W. Preston.

1982 Sociology: An Introduction. 2nd Edition.

New York: St. Martin's Press. 
Spradley, James $P$.

1970 You Owe Yourself a Drunk: An Ethnography of Urban Nomads. Boston: Little, Brown and Company.

1972 "Adaptive Strategies of Urban Nomads: The Ethnosclence of Tramp Culture," Pp. 21-38 in Thomas Weaver and Douglas White (eds.), The Anthropology of Urban Environments. Boulder, Colorado: The Society for Applied Anthropology.

1979 The Ethnographic Interview. New York: Holt, Rinehart and winston.

1980 Participant Observation. New York: Holt, Rinehart and Winston.

Spradley, James $P$. and David W. McCurdy.

1972 The Cultural Experience: Ethnography in Complex Society. Chicago: Science Research Associates, Inc.

Stark, Rodney and Charles Y. Glock.

1968 American Plety: The Nature of Religlous Commitment. Berkeley and Los Angeles, California: University of California Press.

Sweet, William Warren.

1930 The Story of Religions in America. New York: Harper \& Brothers Publishers.

1944 Revivalism in America: It's Origin, Growth and Decline. New York: Charles Scribner's Sons.

Synan, Vinson.

1971 The Holiness-Pentecostal Movement in the United States. Grand Rapids, Michlgan: William B. Eerdmans Publishing Company.

Wallis, Roy, ed.

1975 Sectarlanism: Analyses of Religious and NonReliglous Sects. New York: John Wiley \& Sons.

Walsh, Reverend Vincent $M$.

1975 A Key to Charismatic Renewal in the Catholic Church. St. Melnrad, Indiana: Abbey Press.

W1llems, Em1lo.

1967 "Validation of Authority in Pentecostal Sects of Chile and Brazil." Journal for the Scientific Study of Religion 6:253-258. 
Williams, Melvin D.

1973 "Food and Animals: Behavioral Metaphors in a Black Pentecostal Church in P1ttsburg." Urban Anthropology 2:74-79.

Wilson, B. R.

1963 "A Typology of Sects." Pp. 361-383 in Roland Robertson (ed.), Soclology of Religion. Baltimore, Maryland: Penguin Books Ine.

Wood, W1lliam W.

1965 Culture and Personality Aspects of the Pentecostal Holiness Religion. The Hague-Paris: Mouton \& Co. Publishers. 